\title{
Technologies for Arsenic Removal from Water: Current Status and Future Perspectives
}

\author{
Nina Ricci Nicomel ${ }^{1,2,3}$, Karen Leus ${ }^{2}$, Karel Folens ${ }^{1}$, Pascal Van Der Voort ${ }^{2}$ and \\ Gijs Du Laing 1,*
}

Received: 20 November 2015; Accepted: 17 December 2015; Published: 22 December 2015

Academic Editors: Ravi Naidu and Mohammad Mahmudur Rahman

1 Laboratory of Analytical Chemistry and Applied Ecochemistry, Ghent University, Coupure Links 653, B-9000 Gent, Belgium; nrpnicomel@yahoo.com (N.R.N.); Karel.Folens@UGent.be (K.F.)

2 Department of Inorganic and Physical Chemistry, Center for Ordered Materials, Organometallics and Catalysis (COMOC), Ghent University, Krijgslaan 281-S3, B-9000 Gent, Belgium;

Karen.Leus@UGent.be (K.L.); Pascal.VanDerVoort@UGent.be (P.V.)

3 Department of Engineering Science, College of Engineering and Agro-Industrial Technology, University of the Philippines Los Baños, 4031 Laguna, Philippines

* Correspondence: Gijs.DuLaing@UGent.be; Tel.: +32-9-264-5995

\begin{abstract}
This review paper presents an overview of the available technologies used nowadays for the removal of arsenic species from water. Conventionally applied techniques to remove arsenic species include oxidation, coagulation-flocculation, and membrane techniques. Besides, progress has recently been made on the utility of various nanoparticles for the remediation of contaminated water. A critical analysis of the most widely investigated nanoparticles is presented and promising future research on novel porous materials, such as metal organic frameworks, is suggested.
\end{abstract}

Keywords: arsenic; pollution; water purification technology; engineered nanoparticles; adsorption; metal organic framework

\section{Introduction}

Being the 20th most abundant trace element in the earth's crust, arsenic (As) is a constituent in approximately 245 mineral species, which are predominantly ores containing sulfide, copper, nickel, lead, cobalt, or other metals [1,2]. Arsenic is widely used in various fields such as electronics, agriculture, wood preservation, metallurgy, and medicine [3]. These anthropogenic sources contribute to the release of arsenic to the environment in addition to its release from natural geological sources, for instance, by weathering of arsenic-containing rocks and volcanic activities.

Arsenic is a naturally occurring metalloid that is very mobile in the environment. Its mobility largely depends on the parent mineral form, oxidation state, and mobilization mechanisms [4]. In terms of oxidation state, arsenic can exist in four forms, which are arsenite (As(III)), arsenate $(\operatorname{As}(\mathrm{V}))$, arsenic $(\mathrm{As}(0))$, and arsine $(\mathrm{As}(\mathrm{III}))$. Among these four arsenic species, the most prevalent forms, which are commonly found in water, are the inorganic arsenite and arsenate [5].

Because of slow redox transformations, arsenite and arsenate are present in both reduced and oxidized environments [4]. However, under anoxic reducing conditions (e.g., subsurface waters, reduced sediments), arsenic primarily exists as arsenite, whereas arsenate is prevalent in aerobic oxidizing environments, such as surface waters [6]. The $\mathrm{pH}$ also plays an important role in determining the state of arsenic [7]. Figure 1 shows the Eh-pH diagram of arsenic species in the system As- $\mathrm{O}_{2}-\mathrm{H}_{2} \mathrm{O}$ at a temperature of $25^{\circ} \mathrm{C}$ and total pressure of $101.3 \mathrm{kPa}$. Given a particular $\mathrm{pH}$ and redox potential, the speciation of arsenic, including its oxidation state, can be determined through this diagram [8]. This information is particularly useful in the determination of arsenic toxicity, 
taking the fact that the different arsenic oxidation states possess different toxicities into account [9]. Moreover, considering the fact that negatively charged arsenate (i.e., $\mathrm{H}_{2} \mathrm{AsO}_{4}{ }^{-}$and $\mathrm{HAsO}_{4}{ }^{2-}$ ) is generally much easier to remove compared to uncharged arsenite (i.e., $\mathrm{H}_{3} \mathrm{AsO}_{3}$ ), this Eh-pH diagram can assist in the selection of optimum environmental conditions for arsenic removal [10].

Arsenic is known to be highly toxic to all life forms [11]. This element has been classified by the World Health Organization as a group 1 human carcinogenic substance [12]. Recently, many studies have been conducted regarding the environmental fate and behavior of arsenic due to several arsenic pollution cases worldwide and the hazards associated with these. Upon chronic intake of inorganic arsenic being present in concentrations above $50 \mu \mathrm{g} / \mathrm{L}$ in drinking water, different kinds of skin lesions (e.g., hyperpigmentation, hyperkeratosis) and cancers (e.g., skin, lung, kidney, bladder) can develop, which are collectively termed as arsenicosis [11]. In literature, it is well reported that inorganic arsenic species are more toxic than the organic species mono-methylarsenate (MMA) and dimethylarsinate (DMA). The toxicity of these species increases in the order: DMA-MMA-arsenate-arsenite [13]. As(III) is more harmful for human health than $\mathrm{As}(\mathrm{V})$ as it is more cytotoxic, genotoxic, mobile, and soluble $[5,11,14]$. With the accumulation of trivalent intermediates in the human body, there is a higher possibility of developing arsenic-induced diseases $[15,16]$.

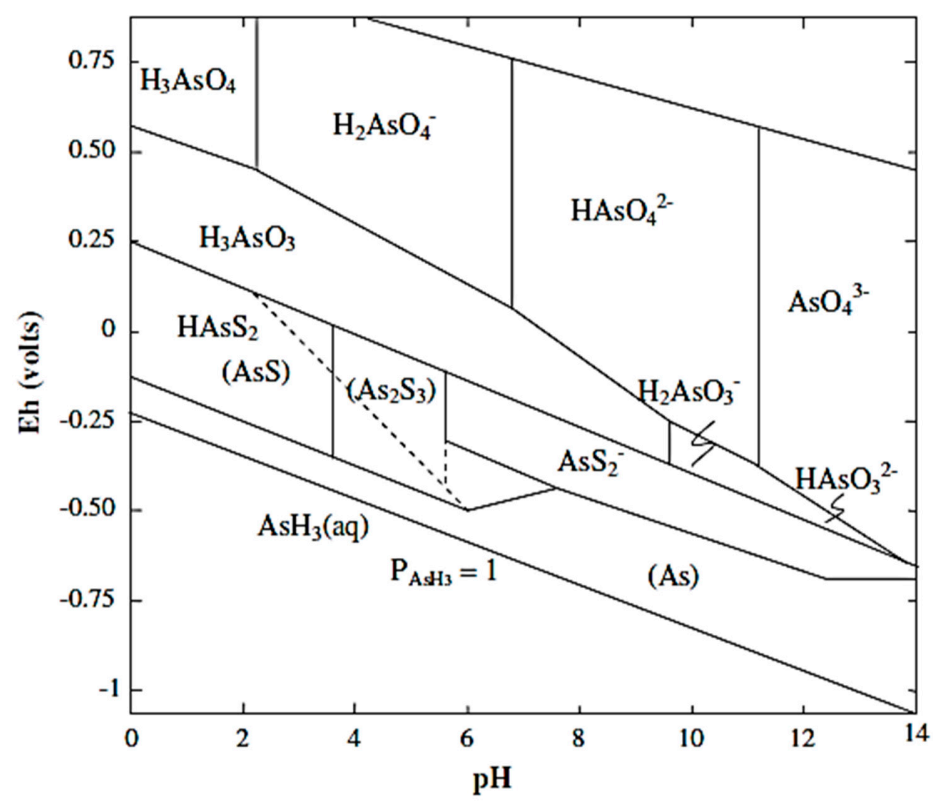

Figure 1. Eh-pH diagram for arsenic at $25^{\circ} \mathrm{C}$ and $101.3 \mathrm{kPa}$ (Adapted with permission from [17]). Arsenite and arsenate are the main species expected in environmentally relevant solutions. More oxic conditions, e.g., surface waters, stimulate the formation of arsenate. Moreover, the threshold potential required to form arsenate is lowered at high $\mathrm{pH}$.

Exposure to arsenic can be through ingestion of arsenic-contaminated water or food and contact with arsenic-contaminated air. Reports have shown that elevated levels of arsenic in drinking water primarily contribute to human arsenic toxicity in the world $[14,18,19]$. Based on World Health Organization $(\mathrm{WHO})$ guidelines, arsenic concentrations in drinking water should be strictly limited to $10 \mu \mathrm{g} / \mathrm{L}$ [6]. As groundwater is generally the main source of drinking water, levels exceeding this standard can often be linked to the contamination of groundwater by geothermal processes, mineral dissolution (e.g., pyrite oxidation), mining activities, desorption in oxidizing environments, and reductive desorption and dissolution [20]. In regions where contaminated drinking water is not the main source of arsenic for inhabitants, intake of food grown in areas with elevated arsenic concentrations in soils and irrigation water represents the primary cause of arsenic toxicity [11,21]. 
In 2012, it was estimated that about 202 million people worldwide are exposed to arsenic concentrations in drinking water above $50 \mu \mathrm{g} / \mathrm{L}$ [18]. Comparing this to an estimate of 130 million people in 2001, it can be inferred that there was a substantial increase in the number of people affected [12].

Worldwide, groundwater arsenic contamination is worst in Asian countries, especially in Bangladesh and West Bengal, India [22,23]. In both areas, the majority of the population depends on tube wells for water supply. Since the arsenic source is geogenic in nature, it has been reported that 79.9 million and 42.7 million people in Bangladesh and India, respectively, are exposed to contaminated groundwater having concentrations above $50 \mu \mathrm{g} / \mathrm{L}[19,24]$. In Bangladesh, the arsenic concentration in some tube wells is as high as $4730 \mu \mathrm{g} / \mathrm{L}$ [22].

For the past three decades, several studies have shown that drinking arsenic-contaminated water should be one of the major concerns for the health of mankind $[25,26]$. Thus, strategies to avoid arsenic contamination of the groundwater and/or to alleviate the impact of such contamination need to be developed in an attempt to reduce the health risks associated with the intake of arsenic-contaminated water. In the following, a comprehensive overview is presented of the conventional techniques used for the removal of As species from water. Moreover, besides the use of nanoparticles for the treatment of arsenic-contaminated water, some novel porous adsorbents will be presented in this work which could act as superior adsorbent materials in the near future due to their outstanding characteristics, e.g., high pore volume and surface area.

\section{Conventional Techniques for Removal of as from Water}

The chemistry and composition of arsenic-contaminated water are the major factors determining the removal of arsenic [11]. Most of the available removal technologies are more efficient for arsenate given that arsenite is predominantly non-charged at $\mathrm{pH}$ below 9.2 [27]. This makes the trivalent form of arsenic less available for precipitation, adsorption, or ion exchange. Accordingly, treatment technologies are believed to be more effective by using a two-step approach consisting of an initial oxidation from arsenite to arsenate followed by a technique for the removal of arsenate [5]. Figure 2 summarizes the presently available technologies that can be used for the removal of arsenic from water.

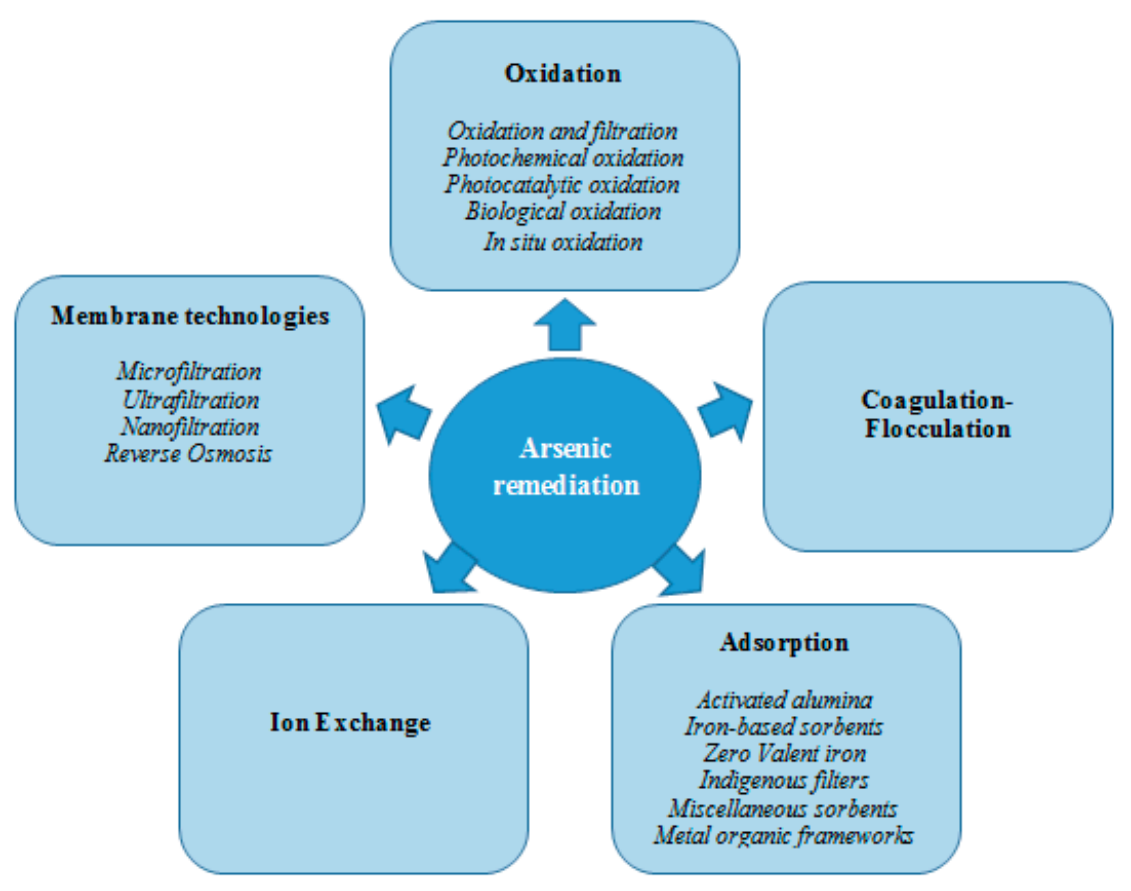

Figure 2. Various techniques used for the removal of arsenic from water. 


\subsection{Arsenic Removal by Oxidation Techniques}

Oxidation involves the conversion of soluble arsenite to arsenate. This alone does not remove arsenic from the solution, thus, a removal technique, such as adsorption, coagulation, or ion exchange, must follow [27]. For anoxic groundwater, oxidation is an important step since arsenite is the prevalent form of arsenic at near neutral $\mathrm{pH}$ [11]. Aside from atmospheric oxygen, many chemicals, as well as bacteria, have already been used to directly oxidize arsenite in water and these are enumerated in Table 1.

Table 1. Different oxidants used to oxidize arsenite to arsenate, their operating conditions, properties, and efficiencies.

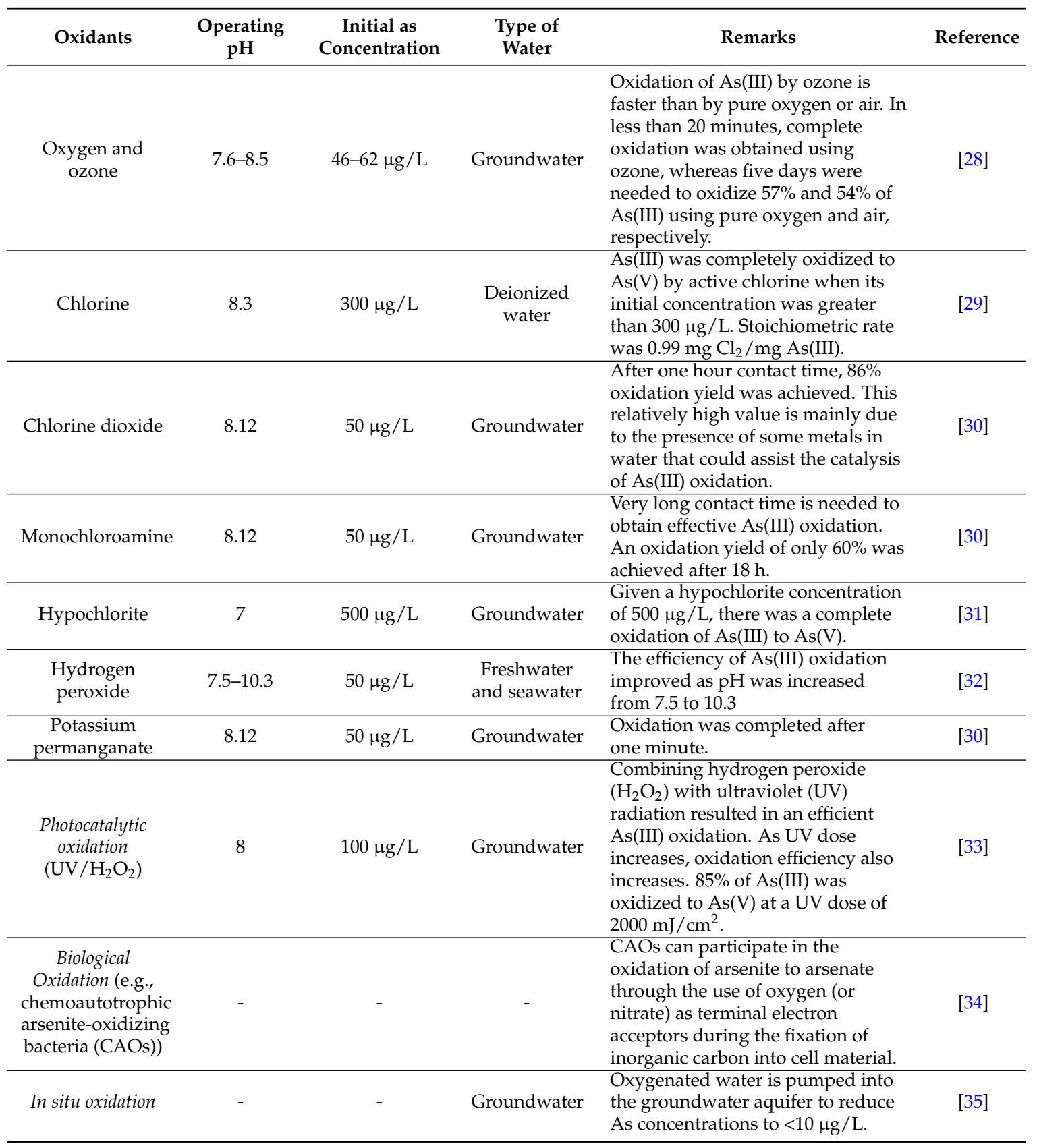

In developing countries, atmospheric oxygen, hypochlorite, and permanganate are the most commonly used oxidants. Oxidation of arsenite with oxygen is a very slow process, which can take hours or weeks to complete [36]. On the other hand, chemicals, such as chlorine, ozone, and 
permanganate, can rapidly oxidize $\mathrm{As}(\mathrm{III})$ to $\mathrm{As}(\mathrm{V})$ as presented in Table 1 . However, despite this enhanced oxidation, interfering substances present in water need to be considered in selecting the proper oxidant as these substances can greatly affect and dictate the kinetics of As(III) oxidation [11]. For instance, the oxidation rate of arsenite by ozone can be greatly reduced if $\mathrm{S}^{2-}$ and TOC are present in water [37]. Also, in another study, it was shown that competing anions and organic matter in groundwater greatly affect the use of $\mathrm{UV} /$ titanium dioxide $\left(\mathrm{TiO}_{2}\right)$ in arsenic oxidation [38]. Furthermore, this involves a complex treatment, which produces an As-bearing residue that is difficult to dispose. Thus, to efficiently remove arsenic from a solution by oxidation, oxidants should be selected carefully. Moreover, all cited disadvantages of oxidation alone make it a less competent method for arsenic removal.

\subsection{Coagulation-Flocculation}

Coagulation and flocculation are among the most employed and documented techniques for arsenic removal from water [27,39]. In coagulation, positively charged coagulants (e.g., aluminum sulphate $\left(\mathrm{Al}_{2}\left(\mathrm{SO}_{4}\right)_{3}\right)$, ferric chloride $\left.\left(\mathrm{FeCl}_{3}\right)\right)$ reduce the negative charge of colloids, thereby making the particles collide and get larger. Flocculation, on the other hand, involves the addition of an anionic flocculant that causes bridging or charge neutralization between the formed larger particles leading to the formation of flocs. During these processes, dissolved arsenic is transformed by the chemicals into an insoluble solid, which undergoes precipitation later [40]. Alternatively, soluble arsenic species can be incorporated into a metal hydroxide phase and be co-precipitated [27]. Either way, solids can be removed afterwards through sedimentation and/or filtration.

Arsenic removal efficiency of different coagulants varies as a function of $\mathrm{pH}$. Below $\mathrm{pH}$ 7.6, $\mathrm{Al}_{2}\left(\mathrm{SO}_{4}\right)_{3}$, and $\mathrm{FeCl}_{3}$ are equally effective in removing arsenic from water [41]. Between the two inorganic arsenic species, most researchers suggested that arsenate is more efficiently removed compared to arsenite and that $\mathrm{FeCl}_{3}$ is a better coagulant than $\mathrm{Al}_{2}\left(\mathrm{SO}_{4}\right)_{3}$ at $\mathrm{pH}$ higher than 7.6 [41-45]. However, despite their reported inferior performance compared to ferric chloride, aluminum-based coagulants were still able to reduce arsenic concentrations to below the maximum concentration level (MCL) of $10 \mu \mathrm{g} / \mathrm{L}$ given that the initial concentration is $280 \mu \mathrm{g} / \mathrm{L}$ [29]. Table 2 shows a list of the coagulants used in arsenic removal, together with their operating conditions, properties, and efficiencies.

Table 2. Different coagulants used to remove arsenic, their operating conditions, properties, and efficiencies.

\begin{tabular}{|c|c|c|c|c|c|}
\hline Coagulant & $\begin{array}{c}\text { Operating } \\
\text { pH }\end{array}$ & $\begin{array}{c}\text { Initial as } \\
\text { Concentration }\end{array}$ & $\begin{array}{l}\text { Type of } \\
\text { Water }\end{array}$ & Remarks & Reference \\
\hline Ferric Chloride & 7.0 & $2 \mathrm{mg} / \mathrm{L}$ & $\begin{array}{c}\text { Distilled } \\
\text { water }\end{array}$ & $\begin{array}{l}\text { At an optimum } \mathrm{FeCl}_{3} \text { dosage of } 30 \\
\mathrm{mg} / \mathrm{L}, \mathrm{As}(\mathrm{III}) \text { and } \mathrm{As}(\mathrm{V}) \text { removal } \\
\text { efficiencies were approximately } 45 \% \\
\text { and } 75 \% \text {, respectively. Arsenic } \\
\text { removal was enhanced at higher } \\
\mathrm{FeCl}_{3} \text { concentrations, however, } \\
\text { residual iron after coagulation } \\
\text { exceeded MCL of iron in } \\
\text { drinking water. }\end{array}$ & [46] \\
\hline Alum & 7.0 & $20 \mu \mathrm{g} / \mathrm{L}$ & River water & $\begin{array}{l}\text { About } 90 \% \text { of initial } \mathrm{As}(\mathrm{V}) \\
\text { concentration was removed from the } \\
\text { solution using } 40 \mathrm{mg} / \mathrm{L} \mathrm{Al}_{2}\left(\mathrm{SO}_{4}\right)_{3} \cdot 18 \\
\mathrm{H}_{2} \mathrm{O} . \mathrm{As}(\mathrm{III}) \text { removal with alum was } \\
\text { negligible even at higher alum doses. }\end{array}$ & [47] \\
\hline
\end{tabular}


Table 2. Cont

\begin{tabular}{|c|c|c|c|c|c|}
\hline Coagulant & $\begin{array}{c}\text { Operating } \\
\text { pH }\end{array}$ & $\begin{array}{c}\text { Initial as } \\
\text { Concentration }\end{array}$ & $\begin{array}{l}\text { Type of } \\
\text { Water }\end{array}$ & Remarks & Reference \\
\hline $\begin{array}{c}\text { Zirconium(IV) } \\
\text { Chloride }\end{array}$ & 7.5 & $50 \mu \mathrm{g} / \mathrm{L}$ & $\begin{array}{l}\text { Distilled } \\
\text { water }\end{array}$ & $\begin{array}{l}\text { The percentage removal of } \mathrm{As}(\mathrm{V}) \\
\text { with } 2 \mathrm{mg} / \mathrm{L} \mathrm{ZrCl}_{4} \text { dosage was } \\
\text { approximately } 55 \% \text {. This value } \\
\text { increased at } \mathrm{pH} 6.5 \text { and decreased at } \\
\mathrm{pH} 8.5 \text {. In contrast to that of } \mathrm{As}(\mathrm{V}) \text {, } \\
\text { the removal efficiency of } \mathrm{As}(\mathrm{III}) \mathrm{was} \\
\text { approximately } 8 \% \text { regardless of } \mathrm{pH} \text {. }\end{array}$ & [48] \\
\hline $\begin{array}{c}\text { Titanium(III) } \\
\text { Chloride }\end{array}$ & 7.5 & $50 \mu \mathrm{g} / \mathrm{L}$ & $\begin{array}{l}\text { Distilled } \\
\text { water }\end{array}$ & $\begin{array}{l}\text { With } 2 \mathrm{mg} / \mathrm{L} \mathrm{TiCl}_{3}, \mathrm{As}(\mathrm{III}) \text { and } \mathrm{As}(\mathrm{V}) \\
\text { removal efficiencies of } 32 \% \text { and } 75 \% \\
\text { were achieved, respectively. Both } \\
\mathrm{As}(\mathrm{III}) \text { and } \mathrm{As}(\mathrm{V}) \text { removal were } \\
\text { highly pH dependent. }\end{array}$ & [48] \\
\hline $\begin{array}{c}\text { Titanium(IV) } \\
\text { Chloride }\end{array}$ & 7.5 & $50 \mu \mathrm{g} / \mathrm{L}$ & $\begin{array}{l}\text { Distilled } \\
\text { water }\end{array}$ & $\begin{array}{l}\text { As }(\mathrm{V}) \text { removal was highly } \mathrm{pH} \\
\text { dependent, whereas } \mathrm{As}(\mathrm{III}) \text { removal } \\
\text { was independent of } \mathrm{pH} \text {. With } 2 \mathrm{mg} / \mathrm{L} \\
\mathrm{TiCl}_{4} \text { dosage, approximately } 55 \% \text { of } \\
\mathrm{As}(\mathrm{V}) \text { was removed, while } \mathrm{As}(\mathrm{III}) \\
\text { removal was } 26 \% \text {. }\end{array}$ & [48] \\
\hline $\begin{array}{l}\text { Titanium(IV) } \\
\text { Oxychloride }\end{array}$ & 7.5 & $50 \mu \mathrm{g} / \mathrm{L}$ & $\begin{array}{l}\text { Distilled } \\
\text { water }\end{array}$ & $\begin{array}{l}\text { Both } \mathrm{As}(\mathrm{V}) \text { and } \mathrm{As}(\mathrm{III}) \text { removal were } \\
\text { pH dependent. The percent removal } \\
\text { of } \mathrm{As}(\mathrm{V}) \text { with } 2 \mathrm{mg} / \mathrm{L} \mathrm{TiOCl}_{2} \text { dosage } \\
\text { was } 37 \% \text {. Given the same conditions, } \\
\text { As(III) removal was about } 20 \% \text {. }\end{array}$ & [48] \\
\hline $\begin{array}{c}\text { Zirconium(IV) } \\
\text { Oxychloride }\end{array}$ & 7.5 & $50 \mu \mathrm{g} / \mathrm{L}$ & $\begin{array}{l}\text { Distilled } \\
\text { water }\end{array}$ & $\begin{array}{l}\text { With } 2 \mathrm{mg} / \mathrm{L} \mathrm{ZrOCl}_{2} \text { dosage, } \\
\text { approximately } 8 \% \text { and } 59 \% \text { of } \mathrm{As}(\mathrm{III}) \\
\text { and } \mathrm{As}(\mathrm{V}) \text { were removed, } \\
\text { respectively. } \mathrm{As}(\mathrm{V}) \text { removal was } \\
\text { highly pH dependent, whereas } \mathrm{As}(\mathrm{III}) \\
\text { removal was independent of pH. }\end{array}$ & [48] \\
\hline Ferric Sulfate & 7.0 & $1 \mathrm{mg} / \mathrm{L}$ & $\begin{array}{c}\text { Double } \\
\text { distilled } \\
\text { water }\end{array}$ & $\begin{array}{l}\text { As(III) removal efficiency of } 80 \% \text { was } \\
\text { achieved with } 25 \mathrm{mg} / \mathrm{L} \mathrm{Fe}_{2}\left(\mathrm{SO}_{4}\right)_{3} \\
\text { dosage. }\end{array}$ & [49] \\
\hline $\begin{array}{l}\text { Titanium(IV) } \\
\text { Sulfate }\end{array}$ & 7.0 & $1 \mathrm{mg} / \mathrm{L}$ & $\begin{array}{l}\text { Double } \\
\text { distilled } \\
\text { water }\end{array}$ & $\begin{array}{l}\mathrm{Ti}\left(\mathrm{SO}_{4}\right)_{2} \text { was employed for enhanced } \\
\text { As(III) removal. The removal } \\
\text { efficiency of As(III) was } 90 \% \text { at a } \\
\text { coagulant dose of } 25 \mathrm{mg} / \mathrm{L} \text {. }\end{array}$ & [49] \\
\hline
\end{tabular}

The major drawback of coagulation-flocculation is the production of high amounts of arsenic-concentrated sludge [11]. The management of this sludge is necessary so as to prevent the consequence of secondary pollution of the environment. Moreover, treatment of sludge is costly. These limitations make this process less feasible, especially in field conditions [40].

\subsection{Membrane Technologies}

In view of drinking water production, membrane filtration is a technique that can be used for the removal of arsenic and other contaminants from water. Typically, membranes are synthetic materials with billions of pores acting as selective barriers, which do not allow some constituents of the water to pass through [50]. A driving force, such as pressure difference between the feed and the permeate sides, is needed to transport the water through the membrane [51]. Generally, there are two categories of pressure-driven membrane filtrations: (i) low-pressure membrane processes, such 
as microfiltration (MF) and ultrafiltration (UF); and (ii) high-pressure membrane processes, such as reverse osmosis (RO) and nanofiltration (NF) $[40,50]$. The characteristics of these four processes are summarized in Table 3.

Table 3. Overview of pressure-driven membrane processes and their characteristics [51,52].

\begin{tabular}{|c|c|c|c|c|}
\hline Parameter & $\begin{array}{l}\text { Microfiltration } \\
\text { (MF) }\end{array}$ & $\begin{array}{l}\text { Ultrafiltration } \\
\text { (UF) }\end{array}$ & Nanofiltration (NF) & $\begin{array}{c}\text { Reverse } \\
\text { Osmosis (RO) }\end{array}$ \\
\hline Permeability $\left(1 /\right.$ h.m ${ }^{2} \cdot$ bar $)$ & $>1000$ & $10-1000$ & $1.5-30$ & $0.05-1.5$ \\
\hline Pressure (bar) & $0.1-2$ & $0.1-5$ & $3-20$ & $5-120$ \\
\hline Pore size (nm) & $100-10,000$ & $2-100$ & $0.5-2$ & $<0.5$ \\
\hline Rejection Monovalent ions & - & - & - & + \\
\hline Multivalent ions & - & $-/+$ & + & + \\
\hline Small organic compounds & - & - & $-1+$ & + \\
\hline Macromolecules & - & + & + & + \\
\hline Particles & + & + & + & + \\
\hline Separation mechanism & Sieving & Sieving & $\begin{array}{l}\text { Sieving Charge } \\
\text { effects }\end{array}$ & Solution-Diffusion \\
\hline Applications & $\begin{array}{l}\text { Clarification; } \\
\text { Pretreatment; } \\
\text { Sterilization }\end{array}$ & $\begin{array}{c}\text { Removal of } \\
\text { macromolecules, } \\
\text { bacteria, viruses }\end{array}$ & $\begin{array}{l}\text { Removal of organic } \\
\text { compounds and } \\
\text { some dissolved salts }\end{array}$ & Removal of salts \\
\hline
\end{tabular}

Using membranes with pore sizes between 0.1 and $10 \mu \mathrm{m}$, MF alone cannot be used to remove dissolved arsenic species from arsenic-contaminated water. Thus, the particle size of arsenic-bearing species must be increased prior to MF; the most popular processes for this being coagulation and flocculation [11]. In a study conducted by Han et al. [53], arsenic removal from drinking water was investigated through flocculation and $\mathrm{MF}$ wherein ferric chloride $\left(\mathrm{FeCl}_{3}\right)$ and ferric sulphate $\left(\mathrm{Fe}_{2}\left(\mathrm{SO}_{4}\right)_{3}\right)$ were used as flocculants. Results showed that flocculation before MF leads to effective arsenic binding onto the ferric complexes present and subsequent arsenic removal in the permeate. However, the $\mathrm{pH}$ of the water and the presence of other ions are major factors affecting the efficiency of this arsenic immobilization. This can be a disadvantage of this technique especially when dealing with arsenite removal as this arsenic form has a neutral charge in the $\mathrm{pH}$ range of 4-10 [50]. Since arsenate is negatively charged in this $\mathrm{pH}$ range, it can bind by surface complexation resulting in efficient arsenate removal. Thus, for this technique to be effective, complete oxidation of arsenite to arsenate is needed.

In the same way as MF, UF alone is not an effective technique for the treatment of arsenic-contaminated water due to large membrane pores [54]. To make use of this technique in arsenic removal, surfactant-based separation processes such as micellar-enhanced ultrafiltration (MEUF) can be utilized [55,56]. For instance, adding cationic surfactant to contaminated drinking water at a concentration above the critical micelle concentration (CMC) of the water will lead to formation of micelles, which can bind to negatively charged arsenic species. In effect, there will be arsenic removal in the permeate as the surfactant aggregates are large enough to pass through the membrane pores. Several studies have already focused on arsenic removal using MEUF. In one such study, the arsenate removal efficiency of different cationic surfactants was investigated [57]. Among the tested surfactants, hexadecylpyridinium chloride (CPC) showed the highest removal efficiency, i.e., $96 \%$. However, arsenic removal was also reported to decrease with decreasing $\mathrm{pH}$. Moreover, despite the effective removal of arsenic, the concentration of the surfactant in the effluent is so high that it needs to be further treated with powdered activated carbon (PAC) before being discharged to the environment.

Both NF and RO are suitable for the removal from water of dissolved compounds with a molecular weight above $300 \mathrm{~g} / \mathrm{mol}$ [51]. These techniques can significantly reduce the dissolved arsenic level in water given that the feed is free from suspended solids and that arsenic is preferably present as arsenate [58]. In a study conducted by Sato et al. [59], it was shown that the removal efficiency for $\mathrm{As}(\mathrm{V})$ exceeded $85 \%$ for all investigated NF membranes, while that of As(III) was far too low. This is supported by the findings of Uddin et al. [60], who indicated that without oxidation 
of arsenite to arsenate, NF cannot comply with the MCL of arsenic in water. The same is the case for $\mathrm{RO}$, as shown in several studies [50,61].

Although technically not a membrane system, diatomaceous earth (DE) filtration is a process that works very similar to that of membrane filters [62]. DE is a chalky sedimentary material containing fossil-like skeletons of microscopic water plants known as diatoms [63]. The size of diatoms ranges from 5-100 micrometers and are characterized by a porous structure having small openings of about 0.1 micrometer in diameter. The combined effect of small pore sizes and high porosity makes DE one of the most effective filters used to remove small particles at high water filtration rates $[62,63]$. Furthermore, this type of filter is odorless, tasteless, and chemically inert making it safe for filtering drinking water. Misra and Lenz [64] developed a method for removing arsenic and heavy metals from water using precipitated mixed hydroxides followed by DE filtration. In one of the laboratory-scale tests performed, an initial arsenic concentration of $100 \mu \mathrm{g} / \mathrm{L}$ was reduced by $90 \%$ using a reagent dose of $1000 \mathrm{mg} / \mathrm{L}$. However, several drawbacks should also be considered, such as the need for $\mathrm{pH}$ adjustment, reagents, and a long conditioning time [64].

\subsection{Adsorption and Ion Exchange}

Adsorption is a process that uses solids as medium for the removal of substances from gaseous or liquid solutions [11]. Basically, substances are separated from one phase followed by their accumulation at the surface of another. This process is driven mainly by van der Waals forces and electrostatic forces between the adsorbate molecules and the adsorbent surface atoms. This makes it important to characterize first the adsorbent surface properties (e.g., surface area, polarity) before being used for adsorption [39].

A wide variety of sorbents has already been studied in several research areas as shown in Table 4. These include activated carbon, coal, red mud, fly ash, chicken feathers, kaolinite, montmorillonite, goethite, zeolites, activated alumina, titanium dioxide, iron hydroxide, zero-valent iron, chitosan, and cation-exchange resins. The table illustrates that iron-based adsorption is an emerging technique for the treatment of arsenic-contaminated water. This can be explained by the fact that there exists a high affinity between inorganic arsenic species and iron [65]. Iron can remove arsenic from water either by acting as a sorbent, co-precipitant or contaminant-immobilizing agent, or by behaving as a reductant [40].

Adsorption has been reported as the most widely used technique for arsenic removal due to its several advantages including relatively high arsenic removal efficiencies $[66,67]$, easy operation, and handling [68], cost-effectiveness [69], and no sludge production [11]. However, adsorption of arsenic strongly depends on the system's concentration and $\mathrm{pH}$. At low $\mathrm{pH}$, arsenate adsorption is favored, whereas for arsenite, maximum adsorption can be obtained between $\mathrm{pH} 4$ and 9 [70]. Moreover, contaminated water does not only contain arsenic; it is always accompanied by other ions, such as phosphate and silicate, competing for the adsorption sites [71]. Aside from the system's conditions, the effectiveness of adsorption in arsenic removal can also be hindered by the type of adsorbent itself. As shown in Table 4, a number of adsorbents have already been studied for the removal of arsenic from water. However, most conventional adsorbents have irregular pore structures and low specific surface areas, leading to low adsorption capacities. Lack of selectivity, relatively weak interactions with metallic ions, and regeneration difficulties can also confine the ability of these sorbents in lowering arsenic concentrations to levels below MCL [72,73]. 
Table 4. Comparative evaluation of different sorptive media previously used for arsenic removal.

\begin{tabular}{|c|c|c|c|c|c|c|c|c|}
\hline \multirow{2}{*}{ Adsorbent } & \multirow{2}{*}{ Type of Water } & \multirow{2}{*}{$\begin{array}{c}\text { Optimum } \\
\text { pH }\end{array}$} & \multirow{2}{*}{$\begin{array}{c}\text { Adsorbent } \\
\text { Dosage (g/L) }\end{array}$} & \multirow{2}{*}{$\begin{array}{l}\text { Surface Area } \\
\left(\mathrm{m}^{2} / \mathrm{g}\right)\end{array}$} & \multirow{2}{*}{$\begin{array}{c}\text { Temperature } \\
\left({ }^{\circ} \mathrm{C}\right)\end{array}$} & \multicolumn{2}{|c|}{ Sorption Capacity (mg/g) } & \multirow{2}{*}{ References } \\
\hline & & & & & & As(III) & $\mathrm{As}(\mathrm{V})$ & \\
\hline Coconut-shell carbon & Distilled water & 5.0 & 5 & 1200 & 25 & - & 2.40 & [74] \\
\hline Coconut-shell carbon pretreated with $\mathrm{Fe}$ (III) & Distilled water & 5.0 & 10 & - & 25 & - & 4.53 & [74] \\
\hline Coal-based carbon & Distilled water & 5.0 & 5 & 1125 & 25 & - & 4.09 & [74] \\
\hline Copper-impregnated coconut husk carbon & Distilled water & 6.5 & 2 & 206 & 30 & 20.35 & . & [75] \\
\hline Rice polish & Deionized double-distilled water & 7.0 & 20 & 452 & 20 & 0.14 & 0.15 & [76] \\
\hline Sorghum biomass & Deionized water & 5.0 & 10 & - & - & 3.6 & - & [77] \\
\hline Fly ash & Distilled water & 4.0 & 1 & $0.8^{*}$ & 20 & - & 30 & [78] \\
\hline Activated alumina & Drinking water & 7.6 & $1-13$ & 370 & 25 & 0.18 & - & [66] \\
\hline Modified chicken feathers & Synthetic water & 4.0 & 10 & - & 20 & 0.13 & - & [79] \\
\hline Allyl alcohol-treated chicken feathers & Synthetic water & 7.0 & 10 & - & 25 & 0.115 & - & [80] \\
\hline Eggshell membrane & Distilled water & 7.0 & 8 & - & 30 & - & 24.2 & {$[81,82]$} \\
\hline Synthetic zeolite H-MFI-24 & Deionized water & 6.5 & 2 & 450 & 20 & - & 35.8 & [83] \\
\hline Granular titanium dioxide & Groundwater & 7.0 & 1 & 250.7 & 13.4 & 32.4 & 41.4 & [84] \\
\hline Granular ferric hydroxide (GFH) & Deionized-distilled water & 6.5 & 0.25 & $240-300$ & 20 & - & 1.1 & [85] \\
\hline Iron oxide-coated cement & Double-distilled water & 7.0 & 30 & - & 15 & 0.73 & - & [86] \\
\hline Iron oxide-coated sand & Distilled water & 7.5 & 20 & - & 27 & 0.029 & - & [87] \\
\hline Iron-oxide-coated manganese sand (IOCMS) & Deionized water & 7.0 & 5 & $9.18 *$ & 25 & 2.216 & 5.452 & [88] \\
\hline Iron-modified activated carbon & Deionized-distilled water & $7.6-8.0$ & $0.1-20$ & 723 & $20-23$ & 38.8 & 51.3 & [89] \\
\hline Amorphous iron hydroxide & Deionized water & $6.0-8.0$ & 1.6 & - & - & 28.0 & 7.0 & [70] \\
\hline Zero-valent iron & Groundwater & 10.0 & 5 & $1.8^{*}$ & 25 & - & 1.92 & [90] \\
\hline Goethite & Deionized water & $6.0-8.0$ & 1.6 & - & - & 22.0 & 4.0 & [70] \\
\hline $\mathrm{Fe}_{\mathrm{x}}(\mathrm{OH})_{\mathrm{y}}$-Montmorillonite & Deionized water & $6.0-8.0$ & 1.6 & 165 & - & 13.0 & 4.0 & [70] \\
\hline $\mathrm{Ti}_{\mathrm{x}} \mathrm{H}_{\mathrm{y}}-$ Montmorillonite & Deionized water & $6.0-8.0$ & 1.6 & 249 & - & 13.0 & 3.0 & [70] \\
\hline Natural siderite & Tap water & 7.31 & 2 & - & 20 & 1.04 & 0.52 & [91] \\
\hline Kaolinite & - & 5.0 & 100 & $33 *$ & 25 & - & 0.86 & [92] \\
\hline Modified calcined bauxite & Double-distilled water & 7.0 & 5 & - & 30 & - & 1.566 & [93] \\
\hline Activated red mud & Distilled water & $7.25 / 3.50$ & 20 & - & 25 & 0.884 & 0.941 & [94] \\
\hline Chitosan resin & Deionized distilled water & 6.0 & 2 & - & 40 & 4.45 & - & [95] \\
\hline Cerium-loaded cation exchange resin & Deionized water & $5.0-6.0$ & 10 & - & 25 & 2.5 & 1.03 & [96] \\
\hline Surface-modified diatomite & Artificial wastewater & 7.0 & - & $50-55 *$ & 25 & - & 8.0 & [97] \\
\hline
\end{tabular}

Brunauer, Emmett and Teller (BET) surface area. 


\section{Application of Nanoparticles for Removal of Arsenic from Water}

Recently, advances in nanoscience and nanotechnology have paved the way to the development of various nanomaterials for the remediation of contaminated water [40]. Due to their high specific surface area, high reactivity, and high specificity, nanoparticles have been given considerable environmental attention as novel adsorbents of contaminants, such as heavy metals and arsenic, from aqueous solutions [98]. Carbon nanotubes and nanocomposites, titanium-based nanoparticles, iron-based nanoparticles, and other metal-based nanoparticles are among the most widely used and investigated nanoparticles for the treatment of arsenic-contaminated water [72,99-101]. Table 5 presents a summary of the comparative evaluation of some nano-adsorbents used for arsenic removal.

\subsection{Carbon Nanotubes (CNTs)}

CNTs have been reported to be effective in the adsorption of various organic chemicals and metal ions after treatment with oxidants [102-104]. In a study conducted by Choudhury et al. [105], As(III) adsorption efficiency of Multiwall CNTs was approximately $34.22 \%$ after $30 \mathrm{~min}$, given an initial As(III) concentration of $542 \mu \mathrm{g} / \mathrm{L}$ and a sorbent concentration of $1 \mathrm{~g} / \mathrm{L}$. Furthermore, the results revealed that Multiwall CNTs are able to remove arsenic to safe limits, but only for a low initial arsenic concentration.

CNTs can also be functionalized in order to increase removal efficiency for metal ions. Velickovic et al. [106] synthesized CNTs functionalized with polyethylene glycol (PEG) for the removal of $\mathrm{As}(\mathrm{V})$ and other metal ions from wastewater. It has been shown that the adsorption of these metal ions on PEG-CNTs is strongly pH dependent. Moreover, for an initial concentration of 10 $\mathrm{mg} / \mathrm{L}$ and $\mathrm{pH}$ equal to 4, the maximum adsorption capacity of $\mathrm{As}(\mathrm{V})$ on this functionalized CNT was found to be $13.0 \mathrm{mg} / \mathrm{g}$.

However, in general, CNTs may not be a better alternative for activated carbon as all-encompassing adsorbents. Nevertheless, CNTs still show potential in some applications wherein only small amounts of materials are required, which implies less material cost. These applications include polishing steps to remove recalcitrant compounds or pre-concentration of trace organic contaminants for analytical purposes [100].

\subsection{Titanium-Based Nanoparticles}

Pena et al. [107] evaluated the effectiveness of nanocrystalline titanium dioxide $\left(\mathrm{TiO}_{2}\right)$ in arsenic removal and in photocatalytic oxidation of As(III). Adsorption of arsenite and arsenate by nanocrystalline $\mathrm{TiO}_{2}$ reached equilibrium within four hours, whereas with commercial nonporous $\mathrm{TiO}_{2}$ particles, it was already reached in an hour. Furthermore, higher adsorption capacity was obtained using nanocrystalline $\mathrm{TiO}_{2}$, which can be due to its higher specific surface area than the nonporous $\mathrm{TiO}_{2}$ particles. At an equilibrium arsenic concentration of $45 \mathrm{~g} / \mathrm{L}$, more than $80 \%$ of both arsenic species was adsorbed by this nano-adsorbent. In terms of oxidation, nanocrystalline $\mathrm{TiO}_{2}$ was also shown as an efficient photocatalyst considering that arsenite was completely converted to arsenate within $25 \mathrm{~min}$ in the presence of sunlight and dissolved oxygen. 
Table 5. Comparative evaluation of various nano-adsorbents for arsenic removal.

\begin{tabular}{|c|c|c|c|c|c|c|c|c|}
\hline \multirow{2}{*}{ Nano-Adsorbent } & \multicolumn{2}{|c|}{ Properties } & \multirow{2}{*}{$\begin{array}{c}\text { Operating } \\
\mathrm{pH}\end{array}$} & \multirow{2}{*}{$\begin{array}{c}\text { Adsorbent } \\
\text { Dosage (mg/L) }\end{array}$} & \multirow{2}{*}{ Temperature $\left({ }^{\circ} \mathrm{C}\right)$} & \multicolumn{2}{|c|}{ Sorption Capacity (mg/g) } & \multirow{2}{*}{ References } \\
\hline & Average Particle Size (nm) & Surface Area $\left(\mathrm{m}^{2} / \mathrm{g}\right)$ & & & & As(III) & $\mathrm{As}(\mathrm{V})$ & \\
\hline $\begin{array}{l}\text { Multiwall carbon nanotubes functionalized with } \\
\text { polyethylene glycol (PEG-MWCNTs) }\end{array}$ & 17.4 & 22.5 & 4.0 & 0.1 & 25 & - & 13.0 & [93] \\
\hline Hydrous titanium dioxide & 4.8 & 312 & 7.0 & 500 & 25 & 83.0 & - & [95] \\
\hline Iron-doped $\mathrm{TiO}_{2}$ & 108.0 & - & 7.0 & 4000 & - & - & 20.4 & [108] \\
\hline Ti-loaded basic yttrium carbonate (Ti-BYC) & $10.0-30.0$ & 82.0 & 7.0 & 1000 & 25 & - & 348.5 & [109] \\
\hline$\alpha-\mathrm{Fe}_{2} \mathrm{O}_{3}$ nanoparticles & 5.0 & 162.0 & 7.0 & 100 & 25 & 95.0 & 47.0 & [104] \\
\hline$\gamma$ - $\mathrm{Fe}_{2} \mathrm{O}_{3}$ nanoparticles & $7.0-12.0$ & 168.73 & - & - & - & 67.02 & - & [110] \\
\hline $\mathrm{Fe}_{2} \mathrm{O}_{3}$ nanoparticles & 12.3 & - & 6.0 & 100 & - & 20.0 & 4.9 & [111] \\
\hline Magnetite nanoparticles & 20.0 & 69.4 & 6.5 & 400 & 25 & 8.0 & 8.8 & [105] \\
\hline $\mathrm{Fe}_{3} \mathrm{O}_{4}$ nanoparticles & 5.0 & 178.48 & 7.0 & 60 & - & 46.06 & 16.56 & [112] \\
\hline Ceria nanoparticles & 6.6 & 86.85 & - & 5000 & 30 & & & [107] \\
\hline $\mathrm{CeO}_{2}-\mathrm{CNT}$ & - & 189.0 & 7.0 & 25 & - & - & 81.9 & [113] \\
\hline Zirconium oxide nanoparticles & 10.8 & 98.0 & 7.0 & 100 & - & 5.2 & 6.0 & [108] \\
\hline Zirconium oxide nanoparticles & - & 327.1 & 7.0 & 100 & 25 & 83.0 & 32.4 & [109] \\
\hline
\end{tabular}

${ }^{*} \mathrm{As}(\mathrm{total})$ 
Another titanium-based nano-adsorbent being used in arsenic removal is hydrous titanium dioxide nanoparticles $\left(\mathrm{TiO}_{2} \times \mathrm{H}_{2} \mathrm{O}\right)$. These offer the advantage of being effective adsorbents for $\mathrm{As}(\mathrm{III})$ without the need for oxidation to $\mathrm{As}(\mathrm{V})$ or any $\mathrm{pH}$ adjustment before and after the adsorption process [38]. Xu et al. [114] synthesized hydrous $\mathrm{TiO}_{2}$ nanoparticles, which were tested for As(III) removal from laboratory-prepared and natural water samples. With a maximum adsorption capacity of $83 \mathrm{mg} / \mathrm{g}$ at near neutral $\mathrm{pH}$ and $96 \mathrm{mg} / \mathrm{g}$ at $\mathrm{pH} \mathrm{9}$, application of $\mathrm{TiO}_{2} \cdot \mathrm{H}_{2} \mathrm{O}$ proved to be an effective, low-cost, and single-step process for the treatment of arsenic-contaminated water. However, because of their size, dispersion of these nanoparticles into the environment is to be expected. Thus, granulation of these nanoparticles into micron-sized particles or loading onto very porous host materials is needed.

A recent study conducted by Lee $e t$ al. [109] showed an enhanced arsenate removal in aqueous solution using Ti-loaded basic yttrium carbonate (BYC). The maximum adsorption capacity of Ti-loaded BYC at pH 7 was reported to be $348.5 \mathrm{mg} / \mathrm{g}$, which is $25 \%$ higher than either BYC or yttrium hydroxide. This can be attributed to its increased specific surface area $\left(82 \mathrm{~m}^{2} / \mathrm{g}\right)$ and surface charge (PZC:8.4). Moreover, Ti-loaded BYC also displayed high adsorption capacities in a wider $\mathrm{pH}$ range ( $\mathrm{pH} 3-11)$. This adsorbent also performed well even in the presence of coexisting anionic species (e.g., phosphate, silicate, bicarbonate). However, this study did not report on the potential of Ti-loaded BYC to adsorb arsenite.

\subsection{Iron-Based Nanoparticles}

Among the most important nanomaterials studied for the treatment of arsenic-contaminated water are iron-based nanoparticles, which include zero-valent iron nanoparticles (nZVI) and iron oxide nanoparticles (i.e., $\mathrm{Fe}_{3} \mathrm{O}_{4}$, and $\gamma-\mathrm{Fe}_{2} \mathrm{O}_{3}$ ). The oxidation state of iron in these particles has a major influence on their capability to remove contaminants [101]. Several mechanisms are involved in these removal processes (Figure 3).

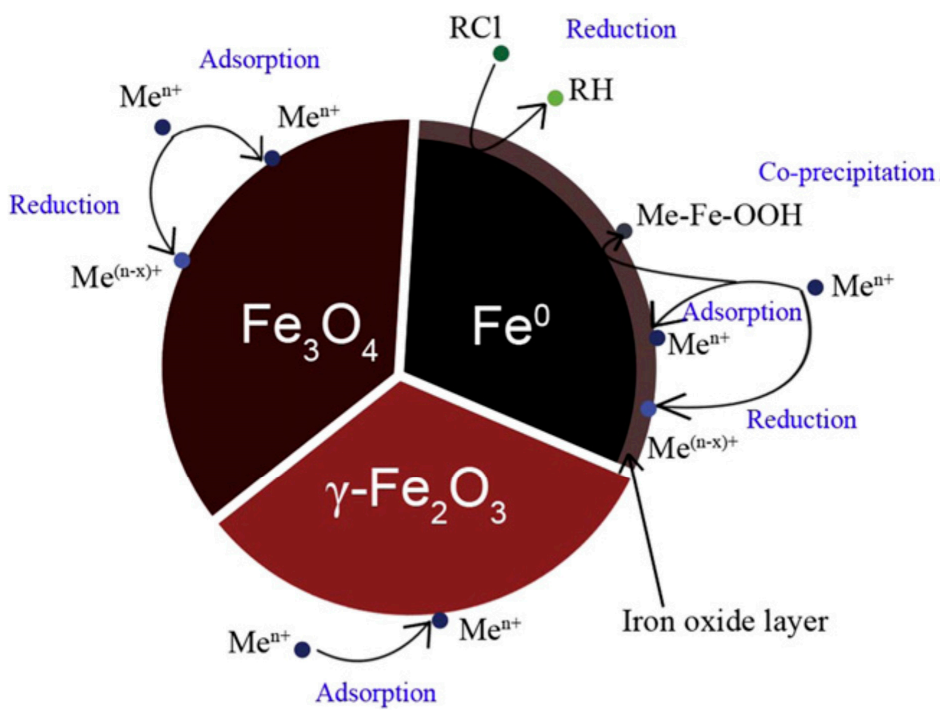

Figure 3. Schematic model of the removal mechanisms of nZVI, $\mathrm{Fe}_{3} \mathrm{O}_{4}$, and $\gamma-\mathrm{Fe}_{2} \mathrm{O}_{3}$ (Adapted with permission from [101]).

\subsubsection{Zero-Valent Iron Nanoparticles (nZVI)}

Several laboratory studies have demonstrated that the application of nZVI is an effective technology for transforming pollutants into their nontoxic form [115]. For instance, dyeing reagents can be adsorbed effectively to functionalized nZVI, which exhibited a maximum adsorption capacity of $191.5 \mathrm{mg} / \mathrm{g}$ for one type of dye studied [116]. In this case, adsorption was the result of 
donor-acceptor bonds formed in the reaction between the functional group $-\mathrm{NH}_{2}$ on the nZVI surface and the $-\mathrm{OH}$ group on the target compound. As for heavy metals, adsorption and co-precipitation are generally accepted mechanisms involved in removal by nZVI [72]. As schematically shown in Figure 3, these mechanisms occur because an iron oxide shell is formed once nZVI is brought in contact with air or water. Removal of arsenic is a widely studied example $[117,118]$.

Using high resolution X-ray photoelectronic spectroscopy (HR-XPS), Ramos et al. [119] studied the arsenic immobilization mechanism using nZVI. Primarily due to the core-shell structure of nZVI, it was shown that both reductive and oxidative mechanisms take place upon application of nZVI. This structure is characterized by a highly reducing metal core and a thin layer of amorphous iron (oxy)hydroxide that helps in the coordination and oxidation of As(III). However, despite this reported advantage of nZVI being a versatile technology for arsenic remediation, other studies also indicated that this nano-adsorbent is disadvantageous when it comes to synthesis [120].

\subsubsection{Iron Oxide Nanoparticles}

Iron oxide nanomaterials are increasingly becoming prevalent in the field of arsenic removal because of their ability to remove arsenic five to ten times more effectively than their micron-sized counterparts [72]. This enhanced uptake capacity for metals, in general, can be attributed to their high surface-to-volume ratios [121]. In addition to this, iron oxide nanoparticles possess magnetic properties, which allow them to be conveniently separated from aqueous solutions [122].

Tang et al. [123] synthesized ultrafine $\alpha-\mathrm{Fe}_{2} \mathrm{O}_{3}$ nanoparticles using a solvent thermal process to treat laboratory-prepared and natural water samples contaminated by arsenic. Studying the kinetics revealed that $\mathrm{As}(\mathrm{III})$ and $\mathrm{As}(\mathrm{V})$ removal by $\alpha-\mathrm{Fe}_{2} \mathrm{O}_{3}$ nanoparticles can be achieved very rapidly. Within the first 30 minutes of contact, around $74 \%$ of $\mathrm{As}$ (III) was already removed with an $\alpha-\mathrm{Fe}_{2} \mathrm{O}_{3}$ loading of $0.04 \mathrm{~g} / \mathrm{L}$ and an initial $\mathrm{As}(\mathrm{III})$ concentration of $0.115 \mathrm{mg} / \mathrm{L}$. For a solution containing $0.095 \mathrm{mg} / \mathrm{L}$ of $\mathrm{As}(\mathrm{V}), 100 \%$ removal was achieved when the $\alpha-\mathrm{Fe}_{2} \mathrm{O}_{3}$ loading was only half of that used for As(III). The synthesized nanomaterial, with a BET specific surface area of $162 \mathrm{~m}^{2} / \mathrm{g}$ and an average particle diameter of $5.0 \mathrm{~nm}$, showed high arsenic adsorption capacities at around neutral $\mathrm{pH}$ conditions. Adsorption capacities for As(III) and As(V) were determined to be $95 \mathrm{mg} / \mathrm{g}$ and $47 \mathrm{mg} / \mathrm{g}$, respectively. Moreover, this study showed that the presence of $\mathrm{Cl}^{-}, \mathrm{NO}_{3}{ }^{-}$, and $\mathrm{SO}_{4}{ }^{2-}$ in the water has only a minimal negative effect on arsenic adsorption. Only $\mathrm{HPO}_{4}{ }^{2-}$ and $\mathrm{SiO}_{3}{ }^{2-}$ could lower the arsenic adsorption substantially, especially the adsorption of $\mathrm{As}(\mathrm{V})$, when the concentrations of these two anions were high.

The performance of magnetite $\left(\mathrm{Fe}_{3} \mathrm{O}_{4}\right)$ nanoparticles in treating arsenic-contaminated water was investigated by Chowdhury and Yanful [124]. This nano-adsorbent has a BET surface area of $69.4 \mathrm{~m}^{2} / \mathrm{g}$ and a mean particle diameter of $20 \mathrm{~nm}$. Results showed that arsenic adsorption by $\mathrm{Fe}_{3} \mathrm{O}_{4}$ nanoparticles is largely dependent on the $\mathrm{pH}$ of the solution, contact time, initial arsenic concentration, $\mathrm{PO}_{4}{ }^{3-}$ concentration in the solution, and the adsorbent concentration. At an initial arsenic concentration of $2 \mathrm{mg} / \mathrm{L}$, maximum adsorption of both arsenic species was achieved at $\mathrm{pH} 2$. Arsenate adsorption decreased rapidly when $\mathrm{pH}$ was above 7 , whereas for arsenite, adsorption was more or less constant in the $\mathrm{pH}$ range 2-9. Furthermore, maximum arsenic adsorption capacities were calculated to be $8.0 \mathrm{mg} / \mathrm{g}$ and $8.8 \mathrm{mg} / \mathrm{g}$ for As(III) and As(V), respectively, using the Langmuir isotherm. The effect of phosphate on arsenic removal was also studied and results showed that removal percentages decreased with increasing phosphate concentration. This result is in accordance with the study conducted by Roy et al. [105] wherein the presence of phosphate at a concentration of $0.5 \mathrm{mg} / \mathrm{L}$ decreased $\mathrm{As}(\mathrm{III})$ and $\mathrm{As}(\mathrm{V})$ removal percentages by $13 \%$ and $25 \%$, respectively.

Mayo et al. [125] also studied $\mathrm{As}(\mathrm{III})$ and $\mathrm{As}(\mathrm{V})$ removal using nanocrystalline magnetite particles. Their results confirmed that the size of the nanoparticles has a significant effect on their adsorption behavior. Adsorption capacities for both arsenic species increased about 200 times when the particle size was decreased from $300 \mathrm{~nm}$ to $12 \mathrm{~nm}$. Hristovski et al. [98] investigated the removal of arsenate through batch experiments carried out using 16 commercially available nanoparticles of 
metal oxides. Most of these nanoparticles removed $>90 \%$ of arsenate from almost all water matrices, with $\mathrm{TiO}_{2}, \mathrm{Fe}_{2} \mathrm{O}_{3}, \mathrm{ZrO}_{2}$, and $\mathrm{NiO}$ nanopowders performing best. These nanoparticles showed the highest removal efficiencies, exceeding $98 \%$, except for $\mathrm{ZrO}_{2}$ in groundwater.

\subsection{Other Metal-Based Nanoparticles}

\subsubsection{Ceria Nanoparticles}

Feng et al. [126] conducted batch experiments to study the adsorption of arsenic on ceria nanoparticles. Results showed that arsenic removal by this nanomaterial is $\mathrm{pH}$-dependent. For arsenate, adsorption increased when the $\mathrm{pH}$ increased from 1 to 6, and then decreased as $\mathrm{pH}$ continued to increase beyond 6. Similar trends were observed for arsenite, although arsenite adsorption was observed to continuously increase in the $\mathrm{pH}$ range from 1 to 8 . Moreover, Langmuir adsorption isotherms revealed that the adsorption capacities of these nanoparticles were $17.08 \mathrm{mg} / \mathrm{g}$, $18.02 \mathrm{mg} / \mathrm{g}$, and $18.15 \mathrm{mg} / \mathrm{g}$ at 10,30 , and $50{ }^{\circ} \mathrm{C}$, respectively, indicating that arsenic adsorption is favored at higher temperatures.

\subsubsection{Zirconium Oxide Nanoparticles}

Being chemically stable, non-toxic, and insoluble, zirconium-based oxides could also be an option for drinking water purification [127]. One of the few studies regarding this group of nanoparticles was conducted by Cui et al. [128]. They synthesized amorphous zirconium oxide $\left(\mathrm{am}-\mathrm{ZrO}_{2}\right)$ nanoparticles by a hydrothermal process for arsenic removal from water. Through kinetics studies, it was shown that by using only a relatively low dosage of am- $\mathrm{ZrO}$ nanoparticles (i.e., $0.10 \mathrm{~g} / \mathrm{L}$ ), arsenic concentrations in water can be reduced to levels below MCL within $12 \mathrm{~h}$ for $\mathrm{As}(\mathrm{V})$ and $24 \mathrm{~h}$ for $\mathrm{As}(\mathrm{III})$. Moreover, the adsorption process was observed to be effective under near neutral $\mathrm{pH}$ conditions and does not need any pretreatment or post-treatment. Maximum adsorption capacities of these am- $\mathrm{ZrO}_{2}$ nanoparticles were found to be $83.2 \mathrm{mg} / \mathrm{g}$ and $32.5 \mathrm{mg} / \mathrm{g}$ for As(III) and As(V), respectively.

\subsection{Disposal of Arsenic-Contaminated Nanoparticles}

The nanoparticles may need to be disposed when their saturation capacity is reached. For other metals and organics, nanoparticles may be recovered through combustion [67]. However, in the case of arsenic-loaded materials, combustion may not be ideal as arsenic oxides are volatile and are easily released to the atmosphere during the combustion process, which creates a new environmental hazard [129]. Therefore, the most attractive option to handle arsenic-loaded nanoparticles currently seems to be encapsulation through stabilization-solidification, followed by secure landfill disposal $[67,130,131]$. The first step, stabilization-solidification, is a popular technique used to convert a potentially hazardous liquid or solid waste into a less or non-hazardous waste before it is disposed in secure landfills [131].

\subsection{Regeneration and Reuse}

In cases where process economy dictates that immediate disposal is not cost-effective, regeneration of the adsorbent seems to be the preferred option. Several studies suggest that the maximum adsorption capacity of metal-based nanoparticle adsorbents remains almost constant after several cycles of regeneration and reuse [132-135]. Moreover, $\mathrm{pH}$ is considered as an important factor in the desorption of metals from the adsorbents. This is in accordance with the results obtained by Tuutijärvi et al. [132] concerning the desorption characteristics of arsenate and the recovery of the adsorbent maghemite $\left(\gamma-\mathrm{Fe}_{2} \mathrm{O}_{3}\right)$ nanoparticles. Among the five alkaline solutions studied (i.e., $\mathrm{NaOH}$, $\mathrm{Na}_{2} \mathrm{CO}_{3}, \mathrm{Na}_{2} \mathrm{HPO}_{4}, \mathrm{NaHCO}_{3}$, and $\mathrm{NaOAc}$ ), $0.1 \mathrm{M} \mathrm{NaOH}$ showed the highest desorption efficiency of $90 \%$. Moreover, desorption was proven to be affected by $\mathrm{pH}$ and the concentration of the alkaline solution. By increasing the concentration of $\mathrm{NaOH}$ to $1 \mathrm{M}$, full desorption of arsenate was achieved. 
However, other authors also reported a reduced adsorption capacity after regeneration. Saiz et al. [129] aimed to analyze the regeneration and reusability of arsenate-loaded $\mathrm{Fe}_{3} \mathrm{O}_{4}{ }^{\circledR} \mathrm{SiO}_{2}$. When comparing $\mathrm{HCl}$ and $\mathrm{NaOH}$, the latter provided the better desorption performance at a concentration of $0.01 \mathrm{M}$. This alkaline condition was further used to evaluate the long-term performance of the regeneration process, wherein sorbent functionalization steps (i.e., protonation of amino groups and coordination of $\mathrm{Fe}^{2+}$ ) were performed in between adsorption and desorption stages. After five adsorption-desorption cycles, the desorption yield decreased by $26 \%$, while the re-adsorption yield only diminished by $5.7 \%$. A decreasing trend of adsorption capacity was also reported by Deliyanni et al. [136] in a study regarding the sorption of $\mathrm{As}(\mathrm{V})$ ions by akaganéite-type nanocrystals. It was found that regeneration of adsorbent was not complete. Moreover, about $25 \%-30 \%$ of akaganéite's capacity was lost in each regeneration step, which means that the adsorbent must be replaced after three or four regeneration steps.

In some aforementioned cases, nanoparticles can be easily regenerated and reused for the removal of arsenic considering that their adsorption capacities are more or less constant even after several cycles of regeneration. This may be an advantage of using nanoparticles as adsorbents. For some nanomaterials not retaining their adsorption capacity during regeneration, this may not be a total disadvantage restricting their potential use as most reagents used in the uncomplicated preparation of these nano-adsorbents are cheap and readily available [129]. In addition, these materials have relatively high adsorption capacities that can outweigh the costs needed to replace the materials after several cycles.

\subsection{Stability Issues}

Nanoparticles have been proven to be effective in the adsorption of heavy metals. However, since they are usually present as fine or ultrafine particles, nanoparticles have low energy barriers, causing them to aggregate and achieve a stabilized state $[99,137]$. Aggregation decreases the free surface area of the nanoparticles, thereby reducing their adsorption capacity and reactivity [101]. Moreover, the mobility of the particles decreases, which further contributes to reducing their effectiveness. To overcome the problems associated with aggregation, two solutions were reported in literature. A first solution is the impregnation of nanoparticles into porous materials or surface coatings [68,138]. Some of the widely used host substrates are activated carbon [139], bentonite [140], sand [141], alumina membranes [142], and ion-exchange resins [143]. As for surface coating, there have been reports mentioning that a thick layer of surface modifiers may reduce the reaction rate, although removal capacity was enhanced due to an increased number of active sites [101]. Thus, tradeoff between stability and reactivity must be studied well. The other solution is the design and synthesis of micronano hierarchically structured sorbents, which can balance high adsorption capacity and nanoparticle stability [144].

\section{Metal Organic Frameworks as Novel Porous Adsorbents}

Metal organic frameworks (MOFs) are porous crystalline hybrid solids that are comprised of inorganic and organic building blocks connected to each other by coordination bonds $[145,146]$. In general, the inorganic components are metal ions or a cluster of metal ions, in which the most often used are the transitional ones, such as $\mathrm{Fe}^{3+}, \mathrm{Zn}^{2+}$, and $\mathrm{Al}^{3+}$. On the other hand, organic components, also known as linkers, are multidentate organic ligands, which can be electrically neutral, anionic, or cationic [147]. Carboxylates are the most widely used anionic linkers due to their ability to make metal ions aggregate, and thus, form more stable networks [148].

Because of their relatively simple and easy synthesis, high surface areas, tunable pore sizes and shape, coordinative unsaturated sites (CUS), and organic functionality, MOFs have gained significant attention in research and industry during the last two decades $[145,149,150]$. Moreover, these hybrid materials showed potential in various fields including hydrogen storage [151], 
gas adsorption [152,153], separation of chemicals [154], catalysis [155], drug delivery [156], magnetism [157], luminescence [158], and sensors [159].

Also, adsorption of hazardous substances from water can be one of the potential applications of MOFs, although their adsorption abilities have been less explored as compared to other materials, such as zeolites $[160,161]$. To some extent, this can be attributed to the fact that only a few classes of MOFs are stable in water for a longer time [162].

In comparison to nanoparticles, MOFs present two major advantages in adsorption applications. First is the presence of CUS or open metal sites in their structure that are readily accessible. Secondly, MOFs have high thermal and mechanical stability making them withstand aggregation problems that are very common in nanoparticles [144]. These advantages, together with their remarkably high porosities and high specific surface areas up to $10,450 \mathrm{~m}^{2} / \mathrm{g}$, make MOFs perform better in removing heavy metals from water than other porous adsorbents [163-165].

Li et al. [166] studied the adsorption of arsenate from water and the characteristics of arsenate removal by MIL-53(Al). It was concluded that the adsorption rate was initially high, which enabled the MOF to reach $80 \%$ of its maximum adsorption capacity within $11 \mathrm{~h}$. At $\mathrm{pH} 8, \mathrm{MIL}-53(\mathrm{Al})$ reached a maximum removal capacity of $105.6 \mathrm{mg} / \mathrm{g}$, which was observed to gradually decrease in strong acidic or alkaline conditions. In addition, a removal capacity of $15.4 \mathrm{mg} / \mathrm{g}$ was obtained at a lower equilibrium concentration of $10 \mu \mathrm{g} / \mathrm{L}$. Through Fourier transform infrared spectroscopy (FT-IR) and X-ray photoelectron spectroscopy (XPS), it was determined that arsenate removal by MIL-53(Al) might be due to electrostatic adsorption and hydrogen bonds. A strong point of this MOF as an adsorbent is that its structure was maintained and no aluminum ions were detected in the water phase after the adsorption. This makes it a suitable material for drinking water treatment. However, the presence of competing anions can hinder the performance of MIL-53(Al) in arsenate adsorption. At a concentration of $1.9 \mathrm{mg} / \mathrm{L}, \mathrm{PO}_{4}{ }^{3-}$ had the greatest impact as it was shown that MIL-53(Al) maintained only $13.5 \%$ of the maximum adsorption capacity (i.e., $105.6 \mathrm{mg} / \mathrm{g}$ ) with the presence of this competing anion.

Zhu et al. [144] also investigated arsenate removal from aqueous solutions using iron and 1,3,5-benzenetricarboxylic MOF (Fe-BTC). This MOF showed relatively high arsenate adsorption capacity of $12.3 \mathrm{mg} / \mathrm{g}$, which is about 2 times and 11 times higher than those of iron oxide $\left(\mathrm{Fe}_{2} \mathrm{O}_{3}\right)$ nanoparticles and commercial iron oxide powders, respectively. Moreover, arsenate can be adsorbed by Fe-BTC in a wide $\mathrm{pH}$ range (i.e., $\mathrm{pH} 2-12$ ). Optimum removal efficiency was observed under acidic conditions. At $\mathrm{pH}$ levels above 12, removal efficiency dropped drastically as the MOF was being dissolved in strong basic conditions. It was also shown in this study that arsenic ions were adsorbed onto the interior of Fe-BTC and not on the outer surface. This explains why this MOF has a higher adsorption capacity compared to $\mathrm{Fe}_{2} \mathrm{O}_{3}$ nanoparticles since it provides more interior space. However, another MOF was reported to have better performance in arsenate removal from aqueous solutions [167]. In this study, MIL-53(Fe) was used with a maximum adsorption capacity of $21.27 \mathrm{mg} / \mathrm{g}$, which is about two times more than that of Fe-BTC.

Zeolitic imidazolate framework-8 (ZIF-8) was also applied as a nano-adsorbent of arsenic species from water in a study conducted by Jian et al. [164]. Maximum adsorption capacities, obtained at a temperature of $25^{\circ} \mathrm{C}$ and $\mathrm{pH} 7$, were 49.49 and $60.03 \mathrm{mg} / \mathrm{g}$ for As(III) and As(V), respectively. ZIF-8 was only stable at neutral and basic conditions as high amounts of $\mathrm{Zn}^{2+}$ were detected in the water in acidic conditions, which decreased the efficiency of arsenic adsorption. Aside from this, the presence of competing anions, such as $\mathrm{PO}_{4}{ }^{3-}$ and $\mathrm{CO}_{3}{ }^{2-}$ can also negatively affect the adsorption of arsenic.

\section{Conclusions and Perspectives}

Arsenic is recognized as a persistent contaminant in groundwater with severe impact on human health when exposed through, amongst other sources, drinking water. Arsenic emissions from natural sources, including not in the least certain Asian countries, and anthropogenic emissions urge for on-site remediation to reduce the toxicity risks. Conventional techniques generally focus 
on arsenate removal after an initial oxidation of arsenite by either atmospheric oxygen, bacterial activity, or chemical reagents. Increasing the particle size of soluble species is possible by a coagulation/flocculation process and allows removal by precipitation or membrane filtration in a consecutive step. Ion-exchange resins alternatively are capable of directly immobilizing As ions, but this process is subject to $\mathrm{pH}$ influences and competition from co-occurring ions such as phosphate or silicate. Nevertheless, practical use of these conventional and non-conventional techniques is still limited due to the fact that their adsorption capacities are still too low and there is a lack of potential to regenerate and reuse the adsorbents.

Nanomaterials made of carbon, titanium, iron, ceria, or zirconium are an emerging class of adsorbents due to their high specific surface areas, high reactivity and high specificity. Nevertheless, the nanoparticles' high surface energies mean they tend to aggregate in aqueous media, which results in a drastic decrease in surface area and therefore in a reduced capacity and selectivity, reducing the process lifetime and potential for real life application.

However, despite the number of studies conducted regarding nanoparticle stabilization for adsorption, little or no attention was given to a novel class of porous materials that was recently gaining considerable attention in other fields of research because of their outstanding properties. These are Metal Organic Frameworks (MOFs), which possess high surface areas, tunable pore sizes and shape, high thermal stability, and a relatively simple synthesis. Moreover, they have the advantages that they can be easily pre- or post-modified on the organic moieties for target specific compounds. MOFs now became subject of exploration for removing hazardous substances such as arsenic or fluoride from contaminated water streams. Their excellent adsorption capacities encourage further development of adsorption technologies towards reaching acceptable arsenic levels.

Acknowledgments: Nina Ricci Nicomel acknowledges funding of the VLIR-UOS. Karen Leus acknowledges the financial support from the Ghent University BOF postdoctoral Grant 01P06813T and UGent GOA Grant 01G00710.

Author Contributions: Gijs Du Laing and Pascal Van Der Voort initiated this study, combining abatement of arsenic pollution problems with novel developments in the field of material sciences. Nina Ricci Nicomel prepared the review of literature with the intense support and assistance of Karen Leus and Karel Folens. All authors have corrected and approved the final manuscript.

Conflicts of Interest: The authors declare no conflict of interest.

\section{References}

1. Lowenbach, W.; Schlessinger, J. Arsenic: A Preliminary Materials Balance; Lowenbach and Schlesinger Associates: Washington, DC, USA, 1979.

2. Mandal, B.; Suzuki, K. Arsenic round the world: A review. Talanta 2002, 58, 201-235. [CrossRef]

3. Sharma, V.; Sohn, M. Aquatic arsenic: Toxicity, speciation, transformations, and remediation. Env. Int. 2009, 35, 743-759. [CrossRef] [PubMed]

4. Al-Abed, S.; Jegadeesan, G.; Purandare, J.; Allen, D. Arsenic release from iron rich mineral processing waste: Influence of ph and redox potential. Chemosphere 2007, 66, 775-782. [CrossRef] [PubMed]

5. Pous, N.; Casentini, B.; Rossetti, S.; Fazi, S.; Puig, S.; Aulenta, F. Anaerobic arsenite oxidation with an electrode serving as the sole electron acceptor: A novel approach to the bioremediation of arsenic-polluted groundwater. J. Hazard. Mater. 2015, 283, 617-622. [CrossRef] [PubMed]

6. WHO. Arsenic in Drinking Water; Organisation, W.H., Ed.; WHO: Geneva, Switzerland, 2011.

7. Henke, K.; Hutchison, A. Arsenic Chemistry; John Wiley \& Sons Ltd.: West Sussex, UK, 2009.

8. Villa-Lojo, M.; Beceiro-Ganzalez, E.; Alonso-Rodriguez, E.; Prada-Rodriguez, D. Arsenic speciation in marine sediments: Effects of redox potential and reducing conditions. Int. J. Env. Anal. Chem. 1997, 68, 377-389. [CrossRef]

9. Ngai, T. Arsenic Speciation and Evaluation of An Adsorption Media in Rupandehi and Nawalparasi Districts of Nepal. Ph.D. Thesis, Massachusetts Institute of Technology, Cambridge, MA, USA, 2002.

10. Association, W.Q. Arsenic Fact Sheet. Available online: https://www.wqa.org/Learn-About-Water/Common -Contaminants / Arsenic (accessed on 15 December 2015). 
11. Singh, R.; Singh, S.; Parihar, P.; Singh, V.; Prasad, S. Arsenic contamination, consequences and remediation techniques: A review. Ecotoxicol. Environ. Saf. 2015, 112, 247-270. [CrossRef] [PubMed]

12. Van Halem, D.; Bakker, S.; Amy, G.; van Dijk, J. Arsenic in drinking water: A worldwide water quality concern for water supply companies. Drinking Water Eng. Sci. 2009, 2, 29-34. [CrossRef]

13. Jain, C.; Ali, I. Arsenic: Occurence, toxicity and speciation techniques. Water Res. 2000, 34, 4303-4312. [CrossRef]

14. Islam, K.; Haque, A.; Karim, R.; Fajol, A.; Hossain, E.; Salam, K.; Hossain, K. Dose-response relationship between arsenic exposure and the serum enzymes for liver function tests in the individuals exposed to arsenic: A cross sectional study in Bangladesh. Environ. Health 2011, 10, 1-11. [CrossRef] [PubMed]

15. Thomas, D.; Waters, S.; Styblo, M. Elucidating the pathway for arsenic methylation. Toxicol. Appl. Pharmacol. 2004, 198, 319-326. [CrossRef] [PubMed]

16. Rossman, T.; Uddin, A.; Burns, F. Evidence that arsenite acts a cocarcinogen in skin cancer. Toxicol. Appl. Pharmacol. 2004, 198, 394-404. [CrossRef] [PubMed]

17. Wang, S.; Mulligan, C. Occurrence of arsenic contamination in Canada: Sources, behavior and distribution. Sci. Total Environ. 2006, 366, 701-721. [CrossRef] [PubMed]

18. Murcott, S. Arsenic Contamination in the World: An. International Sourcebook; IWA Publishing: London, UK, 2012.

19. Ratnaike, R. Acute and chronic arsenic toxicity. Postgrad. Med. J. 2003, 79, 391-396. [CrossRef] [PubMed]

20. Smedley, P.; Kinniburgh, D. A review of the source, behaviour and distribution of arsenic in natural waters. Appl. Geochem. 2002, 17, 517-568. [CrossRef]

21. Zhao, F.-J.; McGrath, S.P.; Meharg, A.A. Arsenic as a food chain contaminant: Mechanisms of plant uptake and metabolism and mitigation strategies. Annu. Rev. Plant. Biol. 2010, 61, 535-559. [PubMed]

22. Chakraborti, D.; Rahman, M.T.; Das, B.; Murrill, M.; Dey, S.; Mukherjee, S.; Quamruzzaman, Q. Status of groundwater arsenic contamination in Bangladesh: A 14-year study report. Water Res. 2010, 44, 5789-5802. [CrossRef] [PubMed]

23. Ahsan, H.; Chen, Y.; Zablotska, L.; Argos, M.; Hussain, I.; Graziano, J.H. Arsenic exposure from drinking water and risk of premalignant skin lesions in bangladesh: Baseline results from the health efects of arsenic longitudinal study. Am. J. Epidemiol. 2006, 163, 1138-1148. [CrossRef] [PubMed]

24. Chen, Y.; Parvez, F.; Gamble, M.; Islam, T.; Ahmed, A.; Argos, M.; Ahsan, H. Arsenic exposure at low-to-moderate levels and skin lesions, arsenic metabolism, neurologcial functions, and biomarkers for respiratory and cardiovascular disease: Review of recent findings from health effects of arsenic longitudinal study in Bangladesh. Toxicol. Appl. Pharmacol. 2009, 239, 184-192. [CrossRef] [PubMed]

25. Maity, J.; Nath, B.; Kar, S.; Chen, C.; Banerjee, S.; Jean, J.; Santra, S. Arsenic-induced health crisis in peri-urban, moyna and Ardebok villages, west Bengal, India: An exposure assessment study. Environ. Geochem. Health 2012, 34, 563-574. [CrossRef] [PubMed]

26. Mazumder, G.; Dasgupta, U. Chronic arsenic toxicity: Studies in west bengal, India. Kaohsiung J. Med. Sci. 2011, 27, 360-370. [CrossRef] [PubMed]

27. Johnston, R.; Heijnen, H. Safe Water Technology for Arsenic Removal. Available online: http:/ /archive.unu.edu/env/Arsenic/Han.pdf (accessed on 18 December 2015).

28. Kim, M.; Nriagu, J. Oxidation of arsenite in groundwater using ozone and oxygen. Sci. Total. Environ. 2000, 247, 71-79. [CrossRef]

29. Hu, C.; Liu, H.; Chen, G.; Jefferson, W.; Qu, J. As(III) oxidation by active chlorine and subsequent removal of $\mathrm{As}(\mathrm{V})$ by al13 polymer coagulation using a novel dual function reagent. Environ. Sci. Technol. 2012, 46, 6776-6782. [CrossRef] [PubMed]

30. Sorlini, S.; Gialdini, F. Conventional oxidation treatments for the removal of arsenic with chlorine dioxide, hypochlorite, potassium permanganate and monochloramine. Water Res. 2010, 44, 5653-5659. [CrossRef] [PubMed]

31. Viet, P.H.; Con, T.H.; Ha, C.T.; Ha, H.V.; Berg, M.; Giger, W.; Schertenleib, R. Investigation of Arsenic Removal Technologies for Drinking Water in Vietnam. In Proceeding of the Fifth International Conference on Arsenic Exposure and Health Effects; San Diego, CA, USA, 14-18 July 2002, Elsevier: Amsterdam, The Netherlands, 2003; pp. 459-469.

32. Pettine, M.; Campanella, L.; Millero, F.J. Arsenite oxidation by $\mathrm{H}_{2} \mathrm{O}_{2}$ in aqueous solutions. Geochim. Cosmochim. Acta 1999, 63, 2727-2735. [CrossRef] 
33. Sorlini, S.; Gialdini, F.; Stefan, M. Uv/h2o2 oxidation of arsenic and tertbutylazine in drinking water. Environ. Monit. Assess. 2014, 186, 1311-1316. [CrossRef] [PubMed]

34. Katsoyiannis, I.; Zouboulis, A. Application of biological processes for the removal of arsenic from groundwaters. Water Res. 2004, 38, 17-26. [CrossRef] [PubMed]

35. Sen Gupta, B.; Chatterjee, S.; Rott, U.; Kaufman, H.; Bandopadyay, A.; DeGroot, W.; Mukhjerjee, S. A simple chemical free arsenic removal method for community water supply-A case study from west Bengal, India. Environ. Pollut. 2009, 157, 3351-3353. [CrossRef] [PubMed]

36. Ahmed, M.F. An overview of arsenic removal technologies in Bangladesh and India. Technol. Arsenic Removal Drinking Water 2001, 251-269.

37. Dodd, M.; Vu, N.; Ammann, A.; Le, V.; Kissner, R.; Pham, H.; Gunten, U. Kinetics and mechanistic aspects of As(III) oxidation by aqueous chlorine, chloramines, and ozone: Relevance to drinking water treatment. Environ. Sci. Technol. 2006, 40, 3285-3292. [CrossRef] [PubMed]

38. Guan, X.; Du, J.; Meng, X.; Sun, Y.; Sun, B.; Hu, Q. Application of titanium dioxide in arsenic removal from water: A review. J. Hazard. Mater. 2012, 27, 360-370. [CrossRef] [PubMed]

39. Choong, T.; Chuah, T.; Robiah, Y.; Gregory, K.; Azni, I. Arsenic toxicity, health hazards and removal techniques from water: An overview. Desalination 2007, 217, 139-166. [CrossRef]

40. Mondal, P.; Bhowmick, S.; Chatterjee, D.; Figoli, A.; Van der Bruggen, B. Remediation of inorganic arsenic in groundwater for safe water supply: A critical assessment of technological solutions. Chemosphere 2013, 92, 157-170. [CrossRef] [PubMed]

41. Garelick, H.; Dybdowska, A.; Valsami-Jones, E.; Priest, N. Remediation technologies for arsenic contaminated drinking waters. J. Soils Sediments 2005, 5, 182-190. [CrossRef]

42. Cheng, R.; Liang, S.; Wang, H.; Beuhler, M. Enhanced coagulation for arsenic removal. J. Am. Water Work Assoc. 1994, 86, 79-90.

43. Hering, J.; Chen, P.; Wilkie, J.; Elimelech, M.; Liang, S. Arsenic removal by ferric chloride. J. Am. Water Work Assoc. 1996, 88, 155-167.

44. Saha, J.; Dikshit, K.; Bandyopadyay, M. Comparative Studies for Selection of Technologies for Arsenic Removal from Drinking Water. Available online: http://archive.unu.edu/env/Arsenic/Saha.pdf (accessed on 18 December 2015).

45. Scott, K.; Green, J.; Do, H.; Mclean, S. Arsenic removal by coagulation. Am. Water Work Assoc. 1995, 87, 114-126.

46. Hesami, F.; Bina, B.; Ebrahimi, A.; Amin, M.M. Arsenic removal by coagulation using ferric chloride and chitosan from water. Int. J. Environ. Health Eng. 2013, 2, 1-6.

47. Hering, J.; Chen, P.-Y.; Wilkie, J.; Elimelech, M. Arsenic removal from drinking water during coagulation. J. Environ. Eng. 1997, 800-807. [CrossRef]

48. Lakshmanan, D.; Clifford, D.; Samanta, G. Arsenic removal by coagulation: With aluminum, iron, titanium, and zirconium. Am. Water Work Assoc. 2008, 100, 76.

49. Sun, Y.; Zhou, G.; Xiong, X.; Guan, X.; Li, L.; Bao, H. Enhanced arsenite removal from water by $\mathrm{Ti}\left(\mathrm{SO}_{4}\right)_{2}$ coagulation. Water Res. 2013, 47, 4340-4348. [CrossRef] [PubMed]

50. Shih, M. An overview of arsenic removal by pressure-driven membrane processes. Desalination 2005, 172, 85-97. [CrossRef]

51. Van der Bruggen, B.; Vandecasteele, C.; Gestel, T.; Doyen, W.; Leysen, R. A review of pressure-driven membrane processes in wastewater treatment and drinking water production. Environ. Prog. 2003, 22, 46-56. [CrossRef]

52. Bottino, A.; Capannelli, G.; Comite, A.; Ferrari, F.; Firpo, R.; Venzano, S. Membrane technologies for water treatment and agroindustrial sectors. Comtes Rendus Chim. 2009, 12, 882-888. [CrossRef]

53. Han, B.; Runnells, T.; Zimbron, J.; Wickramasinghe, R. Arsenic removal from drinking water by flocculation and microfiltration. Desalination 2002, 145, 293-298. [CrossRef]

54. Velizarov, S.; Crespo, J.; Reis, M. Removal of inorganic anions from drinking water supplies by membrane bio/processes. Rev. Environ. Sci. Biol. 2004, 3, 361-380. [CrossRef]

55. Beolchini, F.; Pagnanelli, F.; De Michelis, I.; Veglio, F. Treatment of concentrated arsenic(V) solutions by micellar enhanced ultrafiltration with high molecular weight cut-off membrane. J. Hazard. Mater. 2007, 148, 116-121. [CrossRef] [PubMed] 
56. Gecol, H.; Ergican, E.; Fuchs, A. Molecular level separation of arsenic (v) from water using cationic surfactant micelles and ultrafiltration membrane. J. Membr. Sci. 2004, 241, 105-119. [CrossRef]

57. Iqbal, J.; Kim, H.; Yang, J.; Baek, K.; Yang, J. Removal of arsenic from groundwater by micellar-enhanced ultrafiltration (MEUF). Chemosphere 2007, 66, 970-976. [CrossRef] [PubMed]

58. Figoli, A.; Cassano, A.; Criscuoli, A.; Mozumder, M.; Uddin, M.; Islam, M.; Drioli, E. Influence of operating parameters on the arsenic removal by nanofiltration. Water Res. 2010, 44, 97-104. [CrossRef] [PubMed]

59. Sato, Y.; Kang, M.; Kamei, T.; Magara, Y. Performance of nanofiltration for arsenic removal. Water Res. 2002, 36, 3371-3377. [CrossRef]

60. Uddin, M.; Mozumder, M.; Figoli, A.; Islam, M.; Drioli, E. Arsenic removal by conventional and membrane technology: An overview. Indian J. Chem. Technol. 2007, 14, 441-450.

61. Brandhuber, P.; Amy, G. Alternative methods for membrane filtration of arsenic from drinking water. Desalination 1998, 117, 1-10. [CrossRef]

62. Bhardwaj, V.; Mirliss, M.J. Diatomaceous Earth filtration for drinking water. In Water Encyclopedia; John Wiley \& Sons, Inc.: New York, NY, USA, 2005.

63. Health, W.S.D. Slow Sand Filtration and Diatomaceous Earth Filtration for Small Water Systems; Environmental Health Programs Division of Drinking Water: Washington, DC, USA, 2003.

64. Misra, M.; Lenz, P. Removal of Arsenic from Drinking and Process Water. Available online: https://www.google.com/patents/WO2003086564A2?cl=en (accessed on 18 December 2015).

65. Gupta, A.; Yunus, M.; Sankararakrishnan, N. Zerovalent iron encapsulated chitosan nanospheres-A novel adsorbent for the removal of total inorganic arsenic from aqueous systems. Chemosphere 2012, 86, 150-155. [CrossRef] [PubMed]

66. Singh, T.; Pant, K. Equilibrium, kinetics and thermodynamic studies for adsorption of As(III) on activated alumina. Sep. Purif. Technol. 2004, 36, 139-147. [CrossRef]

67. Mohan, D.; Pittman, C.U., Jr. Arsenic removal from water/wastewater using adsorbents-A critical review. J. Hazard. Mater. 2007, 142, 1-53. [CrossRef] [PubMed]

68. Jang, M.; Chen, W.; Cannon, F. Preloading hydrous ferric oxide into granular activated carbon for arsenic removal. Environ. Sci. Technol. 2008, 42, 3369-3374. [CrossRef] [PubMed]

69. Anjum, A.; Lokeswari, P.; Kaur, M.; Datta, M. Removal of As(III) from aqueous solution using montmorillonite. J. Chromatogr. B 2011, 1, 25-30. [CrossRef]

70. Lenoble, V.; Bouras, O.; Deluchat, V.; Serpaud, B.; Bollinger, J. Arsenic adsorption onto pillared clays and iron oxides. J. Colloid Interface Sci. 2002, 225, 52-58. [CrossRef]

71. Giles, D.; Mohapatra, M.; Issa, T.; Anand, S.; Singh, P. Iron and aluminium based adsorption strategies for removing arsenic from drinking water. J. Environ. Manag. 2011, 92, 3011-3022. [CrossRef] [PubMed]

72. Habuda-Stanic, M.; Nujic, M. Arsenic removal by nanoparticles: A review. Environ. Sci. Pollut. Res. 2015, 22, 8094-8123. [CrossRef] [PubMed]

73. Samiey, B.; Cheng, C.; Wu, J. Organic-inorganic hybrid polymers as adsorbents for removal of heavy metal ions from solutions: A review. Materials 2014, 7, 673-726. [CrossRef]

74. Lorenzen, L.; Deventer, J.; Landi, W. Factors affecting the mechanism of the adsorption of arsenic species on activated carbon. Miner. Eng. 1995, 8, 557-569. [CrossRef]

75. Manju, G.; Raji, C.; Anirudhan, T. Evaluation of coconut husk carbon for the removal of arsenic from water. Water Res. 1998, 32, 3062-3070. [CrossRef]

76. Ranjan, D.; Talat, M.; Hasan, S. Biosorption of arsenic from aqueous solution using agricultural residue 'rice polish'. J. Hazard. Mater. 2009, 166, 1050-1059. [CrossRef] [PubMed]

77. Haque, M.; Morrisson, G.; Perrusquia, G.; Gutierrez, M.; Aguilera, A.; Cano-Aguilera, I.; Gardea-Torresdey, J. Characteristics of arsenic adsorption to sorghum biomass. J. Hazard. Mater. 2007, 145, 30-45. [CrossRef] [PubMed]

78. Diamadopoulos, E.; Ioannidis, S.; Sakellaropoulos, G. As(v) removal from aqueous solutions by fly ash. Water Res. 1993, 27, 1773-1777. [CrossRef]

79. Khosa, M.A.; Wu, J.; Ullah, A. Chemical modification, characterization, and application of chicken feathers as novel biosorbents. RSC Adv. 2013, 3, 20800-20810. [CrossRef]

80. Khosa, M.A.; Ullah, A. In-situ modification, regeneration, and application of keratin biopolymer for arsenic removal. J. Hazard. Mater. 2014, 278, 360-371. [CrossRef] [PubMed] 
81. Khosa, M.A.; Ullah, A. A sustainable role of keratin biopolymer in green chemistry: A review. J. Food Process. Pres. 2013, 1, 8.

82. Ishikawa, S.; Sekine, S.; Miura, N.; Suyama, K.; Arihara, K.; Itoh, M. Removal of selenium and arsenic by animal biopolymers. Biol. Trace Element Res. 2004, 102, 113-127. [CrossRef]

83. Chutia, P.; Kato, S.; Kojima, T.; Satokawa, S. Arsenic adsorption from aqueous solution on synthetic zeolites. J. Hazard. Mater. 2009, 162, 440-447. [CrossRef] [PubMed]

84. Bang, S.; Patel, M.; Lippincott, L.; Meng, X. Removal of arsenic from groundwater by granular titanium dioxide adsorbents. Chemosphere 2005, 60, 389-397. [CrossRef] [PubMed]

85. Banerjee, K.; Amy, G.; Prevost, M.; Nour, S.; Jekel, M.; Gallagher, P.; Blumenschein, C. Kinetic and thermodynamic aspects of adsorption of arsenic onto granular ferric hydroxide (GFH). Water Res. 2008, 42, 3371-3378. [CrossRef] [PubMed]

86. Kundu, S.; Gupta, A. Adsorptive removal of As(III) from aqueous solution using iron oxide coated cement (IOCC): Evaluation of kinetic, equilibrium and thermodynamic models. Sep. Purif. Technol. 2006, 51, 165-172. [CrossRef]

87. Gupta, V.; Saini, V.; Jain, N. Adsorption of As(III) from aqueous solutions by iron oxide-coated sand. J. Colloid Interface Sci. 2005, 288, 55-60. [CrossRef] [PubMed]

88. Wu, K.; Liu, R.; Liu, H.; Zhao, X.; Qu, J. Arsenic(III,V) adsorption on iron-oxide coated manganese sand and quartz sand: Comparison of different carriers and adsorption capacities. Environ. Eng. Sci. 2011, 28, 643-651. [CrossRef]

89. Chen, W.; Parette, R.; Zou, J.; Cannon, F.; Dempsey, B. Arsenic removal by iron-modified activated carbon. Water Res. 2007, 41, 1851-1858. [CrossRef] [PubMed]

90. Sasaki, K.; Nakano, H.; Wilopo, W.; Miura, Y.; Hirajima, T. Sorption and speciation of arsenic by zero-valent iron. Colloids Surf. A Physicochem. Eng. Asp. 2009, 347, 8-17. [CrossRef]

91. Guo, H.; Stüben, D.; Berner, Z. Adsorption of arsenic(III) and arsenic(V) from groundwater using natural siderite as the adsorbent. J. Colloid Interface Sci. 2007, 315, 47-53. [CrossRef] [PubMed]

92. Mohapatra, D.; Mishra, D.; Chaudhury, G.; Das, R. Arsenic adsorption mechanism on clay minerals and its dependence on temperature. Korean J. Chem. Eng. 2007, 24, 426-430. [CrossRef]

93. Bhakat, P.; Gupta, A.; Ayoob, S.; Kundu, S. Investigations on arsenic(V) removal by modified calcined bauxite. Colloids Surf. A Physicochem. Eng. Asp. 2006, 281, 237-245. [CrossRef]

94. Altundogan, H.; Altundogan, S.; Tumen, F.; Bildik, M. Arsenic removal from aqueous solutions by adsorption on red mud. Waste Manage. 2000, 20, 761-767. [CrossRef]

95. Liu, Y.-Y.; Leus, K.; Grzywa, M.; Weinberger, D.; Strubbe, K.; Vrielinck, H.; van Deun, R.; Volkmer, D.; van Speybroeck, V.; van der Voort, P. Synthesis, structural characterization, and catalytic performance of a vanadium-based metal-organic framework (COMOC-3). Eur. J. Inorg. Chem. 2012, 2012, 2819-2827. [CrossRef]

96. Zongliang, H.; Senlin, T.; Ping, N. Adsorption of arsenate and arsenite from aqueous solutions by cerium-loaded cation exchange resin. J. Rare Earth 2012, 30, 563-572.

97. Wu, C.-C.; Wang, Y.-C.; Lin, T.-F.; Tsao, H.-L.; Chen, P.-C. Removal of arsenic from waste water using surface modified diatomite. J. Chin. Inst. Environ. Eng. 2005, 15, 255-261.

98. Hristovski, K.; Baumgardner, A.; Westerhoff, P. Selecting metal oxide nanomaterials for arsenic removal in fixed bed columns: From nanopowders to aggregated nanoparticle media. J. Hazard. Mater. 2007, 147, 265-274. [CrossRef] [PubMed]

99. Hua, M.; Zhang, S.; Pan, B.; Zhang, W.; Lu, L.; Zhang, Q. Heavy metal removal from water/wastewater by nanosized metal oxides: A review. J. Hazard. Mater. 2012, 211-212, 317-331. [CrossRef] [PubMed]

100. Qu, X.; Alvarez, P.; Li, Q. Applications of nanotechnology in water and wastewater treatment. Water Res. 2013, 47, 3931-3946. [CrossRef] [PubMed]

101. Tang, S.; Lo, I. Magnetic nanoparticles: Essential factors for sustainable environmental applications. Water Res. 2013, 47, 2613-2632. [CrossRef] [PubMed]

102. Pan, B.; Xing, B. Adsorption mechanisms of organic chemicals on carbon nanotubes. Environ. Sci Technol. 2008, 42, 9005-9013. [CrossRef] [PubMed]

103. Li, Y.; Wang, S.; Luan, Z.; Ding, J.; Xu, C.; Wu, D. Adsorption of cadmium(II) from aqueous solution by surface oxidized carbon nanotubes. Carbon 2003, 41, 1057-1062. [CrossRef] 
104. Lu, C.; Liu, C. Removal of nickel(II) from aqueous solution by carbon nanotubes. J. Chem. Technol. Biotechnol. 2006, 81, 1932-1940. [CrossRef]

105. Roy, P.; Choudhury, M.; Ali, M. As(III) and As(V) adsorption on magnetite nanoparticles: Adsorption isotherms, effect of ph and phosphate, and adsorption kinetics. Int. J. Chem. Environ. Eng. 2013, 4, 55-63.

106. Velickovic, Z.; Bajic, Z.; Rsitic, M.; Djokic, V.; Marinkovic, A.; Uskokovic, P.; Vuruna, M. Modification of multi-wall carbon nanotubes for the removal of cadmium, lead and arsenic from wastewater. Dig. J. Nanomater Biostruct. 2013, 8, 501-511.

107. Pena, M.; Korfiatis, G.P.; Patel, M.; Lippincott, L.; Meng, X. Adsorption of As(V) and As(III) by nanocrystalline titanium dioxide. Water Res. 2005, 39, 2327-2337. [CrossRef] [PubMed]

108. Nabi, D.; Aslam, I.; Qazi, I.A. Evaluation of the adsorption potential of titanium dioxide nanoparticles for arsenic removal. J. Environ. Sci. China 2009, 21, 402-408. [CrossRef]

109. Lee, S.-H.; Kim, K.-W.; Lee, B.-T.; Bang, S.; Kim, H.; Kang, H.; Jang, A. Enhanced arsenate removal performance in aqueous solution by yttrium-based adsorbents. Int. J. Environ. Res. Public Health 2015, 12, 13523. [CrossRef] [PubMed]

110. Dave, P.; Chopda, L. Application of iron oxide nanomaterials for the removal of heavy metals. J. Nanotechnol. 2014, 246, 572-574. [CrossRef]

111. Luther, S.; Borgfeld, N.; Kim, J.; Parsons, J.G. Removal of arsenic from aqueous solution: A study of the effects of ph and interfering ions using iron oxide nanomaterials. Microchemical. J. 2012, 101, 30-36. [CrossRef]

112. Feng, L.; Cao, M.; Ma, X.; Zhu, Y.; Hu, C. Superparamagnetic high-surface-area $\mathrm{Fe}_{3} \mathrm{O}_{4}$ nanoparticles as adsorbents for arsenic removal. J. Hazard. Mater. 2012, 217-218, 439-446. [CrossRef] [PubMed]

113. Peng, X.; Luan, Z.; Ding, J.; Di, Z.; Li, Y.; Tian, B. Ceria nanoparticles supported on carbon nanotubes for the removal of arsenate from water. Mater. Lett. 2005, 59, 399-403. [CrossRef]

114. Xu, Z.; Li, Q.; Gao, S.; Shang, J. As(III) removal by hydrous titanium dioxide prepared from one-step hydrolysis of aqueous Ticl4 solution. Water Res. 2010, 44, 5713-5721. [CrossRef] [PubMed]

115. Xi, Y.; Mallavarapu, M.; Naidu, R. Reduction and adsorption of $\mathrm{Pb}^{2+}$ in aqueous solutions by nano-zero-valent iron-A sem, tem and xps study. Mater. Res. Bull. 2010, 44, 5713-5721. [CrossRef]

116. Zhang, J.; Liu, Q.; Ding, Y.; Bei, Y. 3-aminopropyltriethoxysilane functionalized nanoscale zero-valent iron for the removal of dyes from aqueous solutions. Pol. J. Chem. Technol. 2011, 13, 35-39. [CrossRef]

117. Kanel, S.; Manning, B.; Charlet, L.; Choi, H. Removal of arsenic(III) from groundwater by nanoscale zero-valent iron. Environ. Sci. Technol. 2005, 39, 1291-1298. [CrossRef] [PubMed]

118. Jegadeesan, G.; Mondal, K.; Lalvani, S. Arsenate remediation using nanosized modified zeovalent iron nanoparticles. Environ. Prog. 2005, 24, 289-296. [CrossRef]

119. Ramos, M.; Yan, W.; Li, X.; Koel, B.; Zhang, W. Simultaneous oxidation and reduction of arsenic by zero-valent iron nanoparticles: Understanding the significance of the core-shell structure. J. Phys. Chem. C 2009, 113, 14591-14594. [CrossRef]

120. Litter, M.; Morgada, M.; Bundschuh, J. Possible treatments for arsenic removal in latin american waters for human consumption. Environ. Pollut. 2010, 158, 1105-1118. [CrossRef] [PubMed]

121. Mohmood, I.; Lopes, C.; Lopes, I.; Ahmad, I.; Duarte, A.; Pereira, E. Nanoscale materials and their use in water contaminants removal-A review. Environ. Sci. Pollut. Res. 2013, 20, 1239-1260. [CrossRef] [PubMed]

122. Sharma, Y.; Srivastava, V.; Singh, V.; Kaul, S.; Weng, C. Nano-adsorbents for the removal of metallic pollutants from water and wastewater. Environ. Technol. 2009, 30, 583-609. [CrossRef] [PubMed]

123. Tang, W.; Li, Q.; Gao, S.; Shang, J. Arsenic (III,V) removal from aqueous solution by ultrafine a-Fe $\mathrm{O}_{3}$ nanoparticles synthesized from solvent thermal method. J. Hazard. Mater. 2011, 192, 131-138. [CrossRef] [PubMed]

124. Chowdhury, S.; Yanful, E. Arsenic removal from aqueous solutions by adsorption on magnetite nanoparticles. Water Environ. J. 2011, 25, 429-437. [CrossRef]

125. Mayo, J.; Yavuz, C.; Yean, S.; Cong, L.; Shipley, H.; Yu, W.; Colvin, V. The effect of nanocrystalline magnetite size on arsenic removal. Sci. Technol. Adv. Mater. 2007, 8, 71-75. [CrossRef]

126. Feng, Q.; Zhang, Z.; Ma, Y.; He, X.; Zhao, Y.; Chai, Z. Adsorption and desorption characteristics of arsenic onto ceria nanoparticles. Nanoscale Res. Lett. 2012, 7, 1-8. [CrossRef] [PubMed] 
127. Cui, H.; Su, Y.; Li, Q.; Gao, S.; Shang, J. Exceptional arsenic (III,V) removal performance of highly porous, nanostructured $\mathrm{ZeO}_{2}$ spheres for fixed bed reactors and the full-scale system modelling. Water Res. 2013, 47, 6258-6268. [CrossRef] [PubMed]

128. Cui, H.; Li, Q.; Gao, S.; Shang, J. Strong adsorption of arsenic species by amorphous zirconium oxide nanoparticles. J. Ind. Eng. Chem. 2012, 18, 1418-1427. [CrossRef]

129. Saiz, J.; Bringas, E.; Ortiz, I. New functionalized magnetic materials for $\mathrm{As}^{5+}$ removal: Adsorbent regeneration and reuse. Ind. Eng. Chem. Res. 2014, 53, 18928-18934. [CrossRef]

130. Bystrzejewska-Piotrowska, G.; Golimowski, J.; Urban, P.L. Nanoparticles: Their potential toxicity, waste and environmental management. Waste Manag. 2009, 29, 2587-2595. [CrossRef] [PubMed]

131. Leist, M.; Casey, R.J.; Caridi, D. The management of arsenic wastes: Problems and prospects. J. Hazard. Mater. 2000, 76, 125-138. [CrossRef]

132. Tuutijärvi, T.; Vahala, R.; Sillanpää, M.; Chen, G. Maghemite nanoparticles for As(V) removal: Desorption characteristics and adsorbent recovery. Environ. Technol. 2012, 33, 1927-1936. [CrossRef] [PubMed]

133. Hu, J.; Chen, G.; Lo, I. Removal and recovery of $\mathrm{Cr}(\mathrm{VI})$ from wastewater by maghemite nanoparticles. Water Res. 2005, 39, 4528-4536. [CrossRef] [PubMed]

134. Hu, J.; Chen, G.; Lo, I.; Asce, M. Selective removal of heavy metals from industrial wastewater using maghemite nanoparticle: Performance and mechanisms. Environ. Technol. 2006. [CrossRef]

135. Banerjee, S.; Chen, D. Fast removal of copper ions by gum arabic modified magnetic nano-adsorbent. J. Hazard. Mater. 2007, 147, 792-799. [CrossRef] [PubMed]

136. Deliyanni, E.; Bakoyannakis, D.; Zouboulis, A.; Matis, K. Sorption of As(V) ions bu akagenetite-type nanocrystals. Chemosphere 2003, 50, 155-163. [CrossRef]

137. Petosa, A.; Jaisi, D.; Quevedo, I.; Elimelech, M.; Tufenkji, N. Aggregation and deposition of engineered nanomaterials in aquatic environments: Role of physicochemical interactions. Environ. Sci. Technol. 2010, 44, 6532-6549. [CrossRef] [PubMed]

138. Chang, Y.; Chen, D. Preparation and adsorption properties of monodisperse chitosan-bound $\mathrm{Fe}_{3} \mathrm{O}_{4}$ magnetic nanoparticles for removal of $\mathrm{Cu}$ (II) ion. J. Colloid Interface Sci. 2005, 283, 446-451. [CrossRef] [PubMed]

139. Kikuchi, Y.; Qian, Q.; Machida, M.; Tatsumoto, H. Effect of zno loading to activated carbon on $\mathrm{Pb}(\mathrm{II})$ adsorption from aqueous solution. Carbon 2006, 44, 195-202. [CrossRef]

140. Eren, E.; Tabak, A.; Eren, B. Performance of magnesium oxide-coated bentonite in removal process of copper ions from aqueous solution. Desalination 2010, 257, 163-169. [CrossRef]

141. Boujelben, N.; Bouzid, J.; Elouear, Z.; Feki, M. Retention of nickel from aqueous solutions using iron oxide and manganese oxide coated sand: Kinetic and thermodynamic studies. Environ. Technol. 2010, 31, 1623-1634. [CrossRef] [PubMed]

142. Hulteen, J.C.; Chen, H.X.; Chambliss, C.K.; Martin, C.R. Template synthesis of carbon nanotubule and nanofiber arrays. Nanostruct. Mater. 1997, 9, 133-136. [CrossRef]

143. Pan, B.; Qiu, H.; Nie, G.; Xiao, L.; Lu, L. Highly efficient removal of heavy metals by polymer-supported nanosized hydrated Fe(III) oxides: Behavior and xps study. Water Res. 2010, 44, 815-824. [CrossRef] [PubMed]

144. Zhu, B.-J.; Yu, X.-Y.; Jia, Y.; Peng, F.-M.; Sun, B.; Zhang, M.-Y.; Luo, T.; Liu, J.-H.; Huang, X.-J. Iron and 1,3,5-benzenetricarbarboxylic metal-organic coordination polymers prepared by solvothermal method and their application in efficient As(V) removal from aqueous solutions. J. Phys. Chem. 2012, 116, 8601-8607.

145. Hasan, Z.; Jhung, S.H. Removal of hazardous organics from water using metal-organic frameworks (MOFs): Plausible mechanisms for selective adsorptions. J. Hazard. Mater. 2015, 283, 329-339. [CrossRef] [PubMed]

146. Khan, N.; Hasan, Z.; Jhung, S. Adsorptive removal of hazardous materials using metal-organic frameworks (MOFs): A review. J. Hazard. Mater. 2013, 244-245, 444-456. [CrossRef] [PubMed]

147. Shen, L. Synthesis, Characterization and Application of Metal-Organic Frameworks. Ph.D. Thesis, University of Illinois at Urbana-Champaign, Illinois, UO, USA, 2012.

148. Eddaoudi, M.; Moler, D.; Li, H.; Chen, B.; Reineke, T.; O’Keeffe, M.; Yaghi, O. Modular chemistry: Secondary building units as a basis for the design of highly porous and robust metal-organic carboxylate frameworks. Account. Chem. Res. 2001, 34, 319-330. [CrossRef]

149. Kitagawa, S.; Kitaura, R.; Noro, S. Functional porous coordination polymers. Angew. Chem. Int. Ed. Engl. 2004, 43, 2334-2375. [CrossRef] [PubMed] 
150. Yaghi, O.; O'Keeffe, M.; Ockwig, N.; Chae, H.; Eddaoudi, M.; Kim, J.B. Reticular synthesis and design of new materials. Nature 2003, 423, 705-714. [CrossRef] [PubMed]

151. Langmi, H.; Ren, J.; North, B.; Mathe, M.; Bessarabov, D. Hydrogen storage in metal-organic frameworks: A review. Electrochim. Acta 2014, 128, 368-392. [CrossRef]

152. Li, Z.; Qiu, L.; Xu, T.; Wu, Y.; Wang, W.; Wu, Z.; Jiang, X. Ultrasonic synthesis of the microporous metal-organic framework $\mathrm{Cu}_{3}(\mathrm{BTC})_{2}$ at ambient temperature and pressure: An efficient and environmental friendly method. Mater. Lett. 2009, 63, 78-80. [CrossRef]

153. Mu, B.; Walton, K. Adsorption equilibrium of methane and carbon dioxide on porous metal-organic framework Zn-BTB. Adsorption 2011, 17, 777-782. [CrossRef]

154. He, Y.; Zhou, W.; Krishna, R.; Chen, B. Microporous metal-organic frameworks for storage and separation of small hydrocarbons. Chem. Commun. 2012, 48, 11813-11831. [CrossRef] [PubMed]

155. Liu, J.; Chen, L.; Cui, H.; Zhang, J.; Zhang, L.; Su, C. Applications of metal-organic frameworks in heterogeneous supramolecular catalysis. Chem. Soc. Rev. 2014, 43, 6011-6061. [CrossRef] [PubMed]

156. Huxford, R.; Della Rocca, J.; Lin, W. Metal-organic frameworks a potential drug carriers. Curr. Opin. Chem. Biol. 2010, 14, 262-268. [CrossRef] [PubMed]

157. Kurmoo, M. Magnetic metal-organic frameworks. Chem. Soc. Rev. 2009, 38, 1353-1379. [CrossRef] [PubMed]

158. Chandler, B.; Cramb, D.; Shimizu, G. Microporous metal-organic frameworks formed in a stepwise manner from luminescent building blocks. J. Am. Chem. Soc. 2006, 128, 10403-10412. [CrossRef] [PubMed]

159. Chen, B.; Wang, L.; Zapata, F.; Qian, G.; Lobkovsky, E. A luminescent microporous metal-organic framework for the recognition and sensing of anions. J. Am. Chem. Soc. 2008, 130, 6718-6719. [CrossRef] [PubMed]

160. Jia, S.; Zhang, Y.; Liu, Y.; Qin, F.; Ren, H.; Wu, S. Adsorptive removal of dibenzothiophene from model fuels overone-pot synthesized pta ${ }^{\circledR}$ mil-101(Cr) hybrid material. J. Hazard. Mater. 2013, 262, 589-597. [CrossRef] [PubMed]

161. Ungureanu, G.; Santos, S.; Boaventura, R.; Botelho, C. Arsenic and antimony in water and wastewater: Overview of removal techniques with special reference to latest advances in adsorption. J. Environ. Manag. 2015, 151, 326-342. [CrossRef] [PubMed]

162. Low, J.; Benin, A.; Jakubczak, P.; Abrahamian, J.; Faheem, S.; Willis, R. Virtual high troughput screening confirmed experimentally: Porous coordination polymer hydration. J. Am. Chem. Soc. 2009, 131, 15834-15842. [CrossRef] [PubMed]

163. Furukawa, H.; Ko, N.; Go, Y.; Aratani, N.; Choi, S.; Choi, E.; Yaghi, O. Ultrahigh porosity in metal-organic frameworks. Science 2010, 329, 424-428. [CrossRef] [PubMed]

164. Jian, M.; Liu, B.; Zhang, G.; Liu, R.; Zhang, X. Adsorptive removal of arsenic from aqueous solution by zeolitic imidazolate framework-8 (ZIF-8) nanoparticles. Colloids Surf. A Physicochem. Eng. Asp. 2015, 465, 67-76. [CrossRef]

165. Ke, F.; Qiu, L.; Yuan, Y.; Peng, F.-M.; Jiang, X.; Xie, A.; Zhu, J. Thiol-functionalization of metal-organic framework by a facile coordination-based postsynthetic strategy and enhanced removal of $\mathrm{Hg}^{2+}$ from water. J. Hazard. Mater. 2011, 196, 36-43. [CrossRef] [PubMed]

166. Li, J.; Wu, Y.-n.; Li, Z.; Zhu, M.; Li, F. Characteristics of arsenate removal from water by metal-organic frameworks (MOFs). Water Sci. Technol. 2014, 70, 1391-1397. [CrossRef] [PubMed]

167. Vu, T.; Le, G.; Dao, C.; Dang, L.; Nguyen, K.; Nguyen, Q.; Dang, P.; Tran, H.; Duong, Q.; Nguyen, T.; et al. Arsenic removal from aqueous solutions by adsorption using novel mil-53(Fe) as a highly efficient adsorbent. RSD Adv. 2015, 5, 5261-5268. [CrossRef]

(C) 2015 by the authors; licensee MDPI, Basel, Switzerland. This article is an open access article distributed under the terms and conditions of the Creative Commons by Attribution (CC-BY) license (http://creativecommons.org/licenses/by/4.0/). 